\title{
Influence of seep emission on the non-symbiont-bearing fauna and vagrant species at an active giant pockmark in the Gulf of Guinea (Congo-Angola margin)
}

\author{
K. Olu ${ }^{a}{ }^{*}$, J.C. Caprais ${ }^{a}$, J. Galéron ${ }^{a}$, R. Causse ${ }^{b}$, R. von Cosel ${ }^{c}, H$. Budzinski ${ }^{d}, K$ K. Le \\ Ménach $^{d}$, C. Le Roux ${ }^{e}, D$. Levachéf, A. Khripounoff ${ }^{a}$ and M. Sibuet ${ }^{a}$
}

\footnotetext{
a Département Etude des Ecosystèmes Profonds, IFREMER Centre de Brest, BP70-29280, Plouzané, France

${ }^{\text {b } M u s e ́ u m ~ N a t i o n a l ~ d ' H i s t o i r e ~ N a t u r e l l e, ~ U M R ~} 5178$ BOME-DMPA, 43 Rue Cuvier-75231 Cedex 05 Paris, France

c Muséum National d'Histoire Naturelle, USM 602 Taxonomie et Collections, 51-57, Rue Cuvier-75231 Cedex 05 Paris, France

d Université Bordeaux, ISM/LPTC, UMR 5255 CNRS, 351 crs de la Libération, 33405 Talence, France

e Station Biologique de Roscoff, UMR CNRS-UPMC 7144, Place Georges Teissier, 29682 Roscoff, Cedex, France

${ }^{\mathrm{f}}$ TOTAL Exploration Production, CSTJF Avenue Larribau 64018 Pau Cedex, France
}

*: Corresponding author: K. Olu, Tel.: 332982246 57; fax: 332982247 57, email address : Karine.Olu@ifremer.fr

\begin{abstract}
:
Detailed surveying with an ROV found that a dense and diverse cold-seep community colonises a giant pockmark located at $3200 \mathrm{~m}$ depth, $8 \mathrm{~km}$ north from the deep Congo channel. Several types of assemblages, either dominated by Mytilidae and Vesicomyidae bivalves or Siboglinidae polychaetes, are distributed on the $800-\mathrm{m}$ diameter active area. The site is characterised by a most active central zone in a depression with abundant carbonate concretions and high methane fluxes where highdensity clusters of mussels and siboglinids dominate. In contrast, the peripheral zones display large fields of dead and live vesicomyids on soft sediment, with a lower mean density and lower methane concentration in seawater. The associated megafauna includes Alvinocarididae shrimps, echinoids, holothurians of the family Synaptidae, several species of gastropods, two species of galatheids, and Zoarcidae and Ophidiidae fishes. Multivariate analyses of video transect data show that the distribution of these major megafauna species at the pockmark scale is influenced by the habitat heterogeneity due to fluid or gas emission, occurrence of hydrates, substratum variability and by the presence of large symbiont-bearing species. Several assemblages dominated either by mytilids, vesicomyids, or siboglinids have been sampled for megafauna densities and biomass estimations and stable isotope measurements $\left(\delta^{13} \mathrm{C}\right.$ and $\left.\delta^{15} \mathrm{~N}\right)$ of dominant species and food sources. The highest estimates of megafauna densities have been obtained in mytilid beds. According to their stable isotopes values, non-symbiont-bearing species mainly rely on chemosynthesis-originated carbon, either as primary consumers of chemoautotrophic microorganisms, or at higher trophic level recycling organic matter, or relying on bivalve and tubeworm production. Most of them likely feed on different sources like shrimps, but differences according to habitat have been evidenced. Carbon and nitrogen isotope ratios of galatheids and benthic or benthopelagic fishes captured by trawls at increasing distances from the pockmark provide evidence of the high variability in the proportion of chemosynthesis-originated carbon in their diet, from $15 \%$ to $38 \%$, according to the species captured as far as $4 \mathrm{~km}$ to the site.
\end{abstract}

Keywords: Cold seep; Megafauna; Isotopic signature; Vagrant species; Atlantic Equatorial African margin; Congo-Angola margin 
In deep chemosynthetic environments driven by fluids enriched in methane and sulphide, i.e. hydrothermal vents and cold seeps, extreme habitat heterogeneity and variability suggest that communities are mainly structured by abiotic forces (e.g., Barry et al., 1997; Bergquist et al., 2005; Henry et al., 1992; Levin et al., 2003; MacDonald et al., 2003; Olu et al., 1997; Sahling et al., 2002; Sarrazin et al., 1999; Van Dover, 1995). Nevertheless, the high biomass which characterizes these environments suggests that biotic interactions should also be important community structuring factors at seeps like at vents (Levesque et al., 2003; Micheli et al., 2002; Sarrazin and Juniper, 1999; Tunnicliffe, 1991).

Megafauna, or large-size epifauna at cold seeps, which are associated with biomass-dominant symbiont-bearing species, include high diversity of taxa and almost all the marine phyla (Levin, 2005; Sibuet and Olu, 1998). Diverse communities are probably favoured by substratum heterogeneity that includes both soft bottoms and carbonate concretions, and as well as environmental conditions that are moderate compared to hydrothermal vents. Symbiont-bearing megafauna are also considered as a source of habitat heterogeneity, because they generate extensive habitat complexity (Levin 2005). Megafaunal community structure and diversity are highly variable among seep sites, and are thought to be influenced by factors such as depth, substratum, pelagic or terrestrial inputs (Levin et al., 2000; Levin and Michener, 2002; Sahling et al., 2003; Sibuet and Olu-Le Roy, 2002; Sibuet and Olu, 1998), patch size or age of symbiont-bearing species (Cordes et al., 2005; MacAvoy et al., 2005).

Dense chemosynthetic communities were discovered on a large part of a 800-m-diameter pockmark discovered along the Congo-Angola margin a few kilometres from the Congo deep 
channel (Olu-Le Roy et al., 2007a; Ondréas et al., 2005). These first studies described assemblages visually dominated by symbiont-bearing taxa, Vesicomyidae and Mytilidae bivalves and Siboglinidae polychaetes whose distributions seemed to be controlled by methane fluxes and substratum variability. This giant pockmark is, in fact, a complex (a pockmark 'cluster') of several individual pockmarks of about $100 \mathrm{~m}$ in diameter whose variable activities may contribute to the spatial heterogeneity observed on the seafloor (Ondreas et al. 2005). The distribution of other megafaunal species is probably controlled by habitat heterogeneity occurring at the pockmark scale, which is created both by fluid emission-related patterns and by the symbiont-bearing species, serving as 'ecosystem engineers' according to Levin (2005).

Following Carney (1994), associated fauna may be classified as endemic, colonist, and vagrant, depending on their abundance at seeps compared to background areas. Stable isotopes, which were first used to demonstrate chemosynthesis processes in seep community, and were mainly applied to symbiont-bearing species (Kennicutt II et al., 1992; Paull et al., 1984; Paull et al., 1985; Rau and Hedges, 1979), can be used to estimate trophic dependence of these 'associate' or 'heterotrophic' species on chemosynthetic production (Levin et al., 2000; Levin and Michener, 2002; MacAvoy et al., 2002). Carbon and nitrogen stable isotopes also have been used to decipher nutritional associations among fauna at vents (Colaço et al., 2002; Fisher et al., 1994; Levesque et al., 2006; Polz et al., 1998; Van Dover, 2002; Van Dover and Fry, 1989; Vereshchaka et al., 2000) and, more recently, at seeps (MacAvoy et al., 2005; Van Dover et al., 2003). The fauna closely associated with tube worm aggregations at cold seeps in the Gulf of Mexico obtain the bulk of its nutrition from local sources of primary production (MacAvoy et al. 2005) but the relative importance of chemosynthetic pathways have been suggested to vary regionally with depth and among microhabitats defined by

103 dominant symbiont-bearing species (Levin and Michener, 2002). 
105 The objective of the present study is to assess the influence of seep emissions on the nonsymbiont-bearing megafauna at a giant pockmark recently discovered, and therefore the

107 dependence of these species on the seep energy, by analysing the following: (i) species

108 distribution relative to the distribution of active seeps at the pockmark scale, (ii) densities and

109 biomass at more or less active local seeps, and (iii) isotopic signature of their tissues relative

110 to chemoautotrophic or external sources of carbon and nitrogen. Export of local

111 chemosynthetic biomass by large mobile predators captured in the background of the deep

112 seep site is also estimated from stable isotope measurements.

2. Materials and methods

\subsection{Video survey and image analysis for megafauna distribution}

118 The giant pockmark named 'REGAB' (Ondréas et al. 2005) was explored by the ROV Victor

1196000 in 2001 during the Ifremer-TOTAL collaborative programmes ZAIANGO and 120 BIOZAIRE (Sibuet and Vangriesheim, 2009. This active cold-seep site is located at $3170 \mathrm{~m}$ 121 depth on the Gabon continental margin close to the deep Congo channel $\left(5^{\circ} 47,50^{\prime} \mathrm{S}\right.$; $1229^{\circ} 42^{\prime} 40^{\prime \prime} \mathrm{E}$ ) (Figure 1). In this paper we will use the term 'pockmark' for the whole pockmark 123 area, not to describe individual pockmarks. Regularly spaced video transects were first

124 performed on the whole structure (Figure 2). Different types of faunal assemblages forming 125 clusters were subsequently defined and mapped (Olu-le Roy et al. 2007a; Figure 2) within the 126 pockmark; they were defined as 'chemosynthetic assemblages ' and either dominated by

127 large bushes of the siboglinid polychaete Escarpia southwardae Andersen et al. 2005, or by 128 two species of vesicomyid bivalves undistinguishable on images but identified from samples 
129 as Laubiericoncha chuni (Thiele and Jaeckel, 1931), see Cosel and Olu (2008) and

130 Caplytogena regab Cosel and Olu (2009), or by the Mytilidae Bathymodiolus sp. aff.

131 boomerang (Olu-Le Roy et al., 2007b). The results of a second phase of video analysis,

132 subsequent to the symbiont-bearing species cluster mapping, are presented in this paper.

133 Video surveys of seven dives were analysed in order to map the distribution of megafaunal 134 associate species along the dive tracks, at the pockmark scale. The video sequences from a 135 down-looking camera, which was vertically mounted on the ROV, during 3-m-altitude 136 surveys were analysed for the distribution of visible taxa of at least a 2-cm size, including the 137 largest gastropods, some crustaceans, echinoderms and fishes. Maps of distribution along the 138 dive tracks were compiled for the dominant associated species and compared with the 139 previously acquired distribution maps of symbiont-bearing species, using the ADELIE 140 extension for ArcGIS 9.0 developed at Ifremer. Each taxon record was associated with visual 141 observations of habitat including the following: (i) substratum category (soft sediment, 142 carbonate concretions, hydrate outcrops) and (ii) dominant symbiont-bearing species (living 143 or dead vesciomyids, mytilids, siboglinids) or bacterial mats. Multidimentional scaling 144 (MDS) of the species/biotope matrix of distance using the Bray Curtis distance (Primer 145 software) was performed to identify the relationships between megafauna distribution and 146 habitat characteristics.

147 In order to compare density and biomass of the associated megafauna in the clusters 148 dominated by different symbiont-bearing species, 11 assemblages or 'sites' were selected at 149 different locations on the pockmark, either in the central, more active part of the pockmark 150 for methane emission (Charlou et al., 2004), or in peripheral areas (Table 1). There were 151 three assemblages of different sizes dominated by Bathymodiolus aff. boomerang, five 152 vesicomyid clusters with different proportion of living and dead individuals, and located in 153 the different zones of the pockmark, and two escarpiid E. southwardae one, presumed to be 
adults and the other one juveniles. Density, biomass of dominant symbiont-bearing species

155

156

157

158

160

161

162

163

164

165

166

167

168

169

170

171

172

173

174

175

176

and also chemical characteristics at each site are described in Olu Le Roy et al. (2007a).

Megafaunal species densities, when making density estimates on surfaces, were either estimated from close-up views using four laser points spaced $23 \mathrm{~cm}$ apart or from the scale provided by the ROV's sampling tools. When possible, density was averaged from five to 10 sequential, but non-overlapping images or from complete mosaics of the same site, produced from short video sequences using the ADELIE software. Individual wet weights were estimated from formalin-preserved specimens collected by the ROV grab or suction sampler, and dry weights of same specimens after $48 \mathrm{~h}$ at $60^{\circ} \mathrm{C}$. Species biomass in the assemblages was estimated from three to five specimens of different sizes for each species.

\subsection{Stable isotope measurements}

Carbon and nitrogen isotopic ratios were analysed for three symbiont-bearing species and ten associated species, sampled by ROV in the chemoautotrophic assemblages. Between two and five individuals were analysed for each species. With this sample set, it was possible to correlate isotopic signature to habitat for associated species collected in multiple assemblages that were dominated by different symbiont-bearing species. Specimens used for isotopic measurements were dissected on board; muscle samples were removed and stored in liquid nitrogen. In the laboratory, samples were dried under vacuum and analysed in triplicate for their carbon and nitrogen isotopic ratios $\left(\delta^{13} \mathrm{C}\right.$ and $\left.\delta^{15} \mathrm{~N}\right)$ calculated by a DELTA Plus (thermo Finnigan) isotopic mass spectrometer (LPTC, Bordeaux) and for a few samples by a FINNIGAN DELTA S IRMS (Station Biologique de Roscoff) as follows:

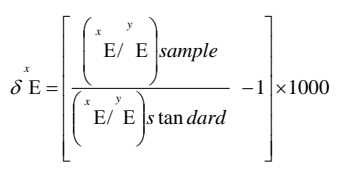


177 where $E$ is the element analysed ( $\mathrm{C}$ or $\mathrm{N}$ ), $x$ is the atomic weight of the heavier isotope, and $y$

178 is the atomic weight of the lighter isotope $(x=13,15$ and $y=12,14$ for $\mathrm{C}$ and $\mathrm{N}$,

179 respectively). The standard materials to which the samples were compared were PDB (Pee

180 Dee Belemnite) for carbon and air N2 for nitrogen. Reproducibility of all measurements was

181 about $0.3 \%$. The standard compounds used to correct samples' values from deviation due to

182 the spectrometer were usg24 (16.1\%) for the carbon and N1 (0.4\%o) for the nitrogen. Inter-

183 comparison of measurements was performed to test the reproducibility of the samples

184 analysed by the two mass spectrometers.

185 In addition to the fauna, sediments from ROV push cores collected adjacent to the different

186 assemblages were analysed after vertical subsampling of 2-cm slices from the interface $(0$

$187 \mathrm{~cm}$ ) to a depth of $6 \mathrm{~cm}$. Isotopic measurements were performed after acidification to remove 188 carbonates. Particles from sediment traps deployed for a year on the REGAB site, at $400 \mathrm{~m}$

189 above the seafloor, were also analysed for carbon and nitrogen isotopic ratios.

190 Methane $\delta^{13} \mathrm{C}$ was measured on sediment from tube-cores (first $5 \mathrm{~cm}$ ) collected in crimping

191 boxes and on water in sealed vials $(20 \mathrm{ml})$ and analysed by Head-Space/Gas

192 Chromatography/Isotope Ratio Mass Spectrometry (HS/GC/IRMS) in Total Laboratory.

193

194 The REGAB and background megafauna were also sampled by beam trawls. Trawl samples 195 were taken at increasing distances from the centre of the pockmark as follow: at 400 196 (peripheral edge), 580, 1560, 3680 and 5800 m, southward (CP19 to CP15), and at 610, 680, 1971660 and 3600 m northward (CP20 to CP23) (Figure 1b). Benthic fishes and galatheids were 198 analysed for their isotopic composition, with particular attention being paid to species 199 collected in the cold-seep site and in the background. Pieces of tail muscles of 38 specimens 200 belonging to 12 species of fishes and abdomen muscles of 9 specimens of galatheids were 201 dissected on board. The proportion of chemosynthetic carbon in the diet of these mobile 
predators or scavengers was estimated with the following isotopic mixing equation proposed by MacAvoy et al. (2002):

$\delta x$ Epredator $-F=(\delta x$ Eseep $\times$ fseep $)+(\delta x$ Eocean $\times(1-$ fseep $))(1)$

where fseep is the fraction of diet from chemosynthetic sources and $\delta x E$ seep and $\delta x E$ ocean are the mean isotopic signatures of the chemosynthetic material and background ocean, respectively. The parameter $F$ corrects for trophic enrichment and is dependent on the isotope used. When using $\delta^{13} \mathrm{C}$ and $\delta^{15} \mathrm{~N}$, F was given a value of 1 and 3.5\%, respectively, which is the trophic enrichment typically associated with these isotopes (Minegawa and Wada, 1984;

Rau et al., 1983) The values used for the mean isotopic signatures of the chemosynthetic

211 prey, $\delta x E$ seep $\left(\delta^{13}\right.$ Cseep and $\delta^{15}$ Nseep), were calculated by averaging values for selected resident fauna exclusive of vagrant species, and for sediment collected at different places in the active site. The phytodetritus-based food sources of the background, $\delta x E$ Ecean, were similarly estimated from values of megafauna species collected in the same beam trawl samples as fishes, except for the one sampling part of the cold-seep site (CP20). This trawl haul (CP20) was performed in the north part of the pockmark and collected some species of the chemoautotrophic assemblages characteristics of the cold-seep site. Some of these species were analysed for their isotopic signature, in order to increase the number of specimens, but were separated in the results, as they cannot be referred to a particular habitat (e.g., mussel bed, etc.) as for ROV samples.

3. Results

\subsection{Distribution of megafauna species all over the pockmark}

224 On the giant pockmark, 10 invertebrate taxa were identified on videos as associate species of chemosynthetic assemblages; their occurrence is reported together with substratum and symbiont-bearing species, to characterise the habitat. A total of 4352 individuals were 
counted along video tracks, with half being galatheids ascribed to Munidopsis sp.. The

228

229

230

231

232

233

234

235

236

237

238

239

240

241

242

243

244 species were not recognizable on the images, but Munidopsis geyeri was more abundant in the samples than was Munidopsis hirtella (Macpherson and Segonzac, 2005). Shrimps described from samples as Alvinocaris muricola (Komai and Segonzac, 2005), holothurians of the genus Chiridota, a species close to Chiridota heveva Pawson and Vance, 2004 (M. Sibuet, pers. com.) and large gastropods of family Turridae, species Phymorhynchus coseli Warén and Bouchet (2009) were also well represented. Other taxa are irregular echinoids and several families of fishes, including the families Zoarcidae, Macrouridae and Ophidiidae, which were the most abundant and easily recognisable. The distribution maps (Figure 3) of the four most abundant taxa (Munidopsis sp., Alvinocaris muricola, Chiridota sp. and echinids) show that, galatheids were observed along the dive tracks throughout the pockmark, while the other species seem to be closely associated with fluid emission, as co-occur with symbiont-bearing species. Shrimps were mainly observed in the central part of the pockmark associated with mytilid and escarpiid assemblages; echinids were only observed in soft sediment areas, in the close vicinity of vesicomyid beds, and holothurians were observed in the entire active area. Multivariate analyses were performed for the entire data set to avoid misinterpretation due to denser sampling coverage in the active region. The result of the multidimensional scaling analysis, using the Bray Curtis distance between species and analysing first the similarity between biotopes (Figure 4a), identified the symbiont-bearing species assemblages (mytilids, vesicomyids and escarpiids), as the exception of dead escarpiid bushes, as a primary habitat for associated megafauna, the bare substratum (soft, reduced sediment, carbonate) as a secondary habitat and hydrate outcrops, dense gas bubbles and bacterial mats as a final one (stress $=0.03$ ). Analysis of the similarity between species (Figure 4b) grouped together Alvinocarid shrimps, Chiridota sp. holothurians, species associated with living symbiont-bearing species assemblages and, to a lesser degree, 
galatheids (stress $=0.02$ ). Whether or not Phymorrhynchus belongs to this group depends on

253

254

255

256

257

258

259

260

261

262

263

264

265

266

267

268

269

270

271

272

273

274

275 the 'classification' or grouping method employed. Its relationship with symbiont-bearing species is much less strong than for other species. The zoarcid fish Lycodes sp. and echinoids are grouped together; they were generally both observed in the close vicinity of symbiontbearing bivalve assemblages. Other fishes and swimming holothurians defined another group, whose distribution is probably independent of that of chemosynthetic fauna.

\subsection{Megafaunal community structure in chemosynthetic assemblages}

The densities of megafaunal species were estimated from images at 10 sites, which were either characterised as vesicomyids, mytilid clusters, or escarpiid bushes (Tables 2a and 2b). The symbiont-bearing species generally show the highest densities in clusters with 31 to $86 \%$ of the total individuals, and largely dominate the megafaunal biomass with $71-76 \%$ in escarpiid bushes and 84-98\% in bivalve clusters. The associated species observed in the symbiont-bearing species clusters are dominated by the shrimps Alvinocaris muricola, independent of the symbiont-bearing species, except in the vesicomyid clusters V1 and Vext. Their very high density, up to 744 ind. $\mathrm{m}^{-2}$ in mytilid beds, 246 ind. $\mathrm{m}^{-2}$ in vesicomyid clusters and 302 ind. $\mathrm{m}^{-2}$ in escarpiid bushes, represents between up to $12 \%$ of the total biomass in dry weight in bivalve clusters and up to $26 \%$ in escarpiid bushes. The gastropods include the Provannidae Provanna reticulata Warén and Bouchet (2009) and Provanna chevalieri Warén and Bouchet (2009) (not distinguishable on images) and the limpet Paralepetopsis sasakii Warén and Bouchet (2009). Both genera have high numerical densities in mytilid beds and adult tube-worm bushes. Nevertheless, owing to their small size, they make a small contribution to the total biomass. In the vesicomyid clusters, their densities are more variable, 
only the Provannidae are present, in association with high bivalve density ( $>500$ ind. $\left./ \mathrm{m}^{2}\right)$.

277 The Turridae Phymorrhynchus coseli is sometimes associated with vesicomyids in soft sediment areas in the SW part of the pockmark in clusters with numerous empty shells (V1,VB). Actiniaria colonise concretions and among mussels. The holothurid Chiridota sp. can be locally abundant, particularly among bivalves, and has higher densities in vesicomyid clusters than in mytilid beds. Munidopsis geyeri is only observed in the clusters located in the periphery areas. The zoarcid fish Lycodes sp. is commonly observed among bivalves, but not with high densities (no more than one or two ind/cluster).

The densities and biomass of associated species were highest in the three mytilid beds (Table 2), whereas among vesicomyid clusters and escarpiid bushes they have lower densities/biomass. These differences are only significant for density and biomass between mytilid and vesicomyids assemblages (Kruskall Wallis test; $\mathrm{p}$ value $<0.05$ ). The densities and biomass are highly variable in vesicomyid clusters, and higher in the adult escarpiid bush than in the juvenile one. Among the vesicomyids, densities of associated species mainly depend on the bivalve density, but also on their location in the pockmark. The clusters located in the central part of the REGAB site (V3 and VC) have higher densities, particularly of Alvinocharis muricola and Provanna sp. than V1 and VB that are located in the peripheral fields and Vext, which is an isolated cluster away from the active part of the pockmark (Figure 2b). Considering the total density of the symbiont-bearing and non-symbiont-bearing species, the density and biomass of mytilid clusters are significantly higher than in the other two cluster types (mean = 1882 ind. $\mathrm{m}^{-2}$, 691 ind. $\mathrm{m}^{-2}$ and 629 ind. $\mathrm{m}^{-2}$, respectively, for vesicomyids and escapiid assemblages).

\subsection{Isotopic measurements}




\subsubsection{Sources: methane, particles from traps and sediment}

302 Methane carbon isotopic ratio measured from sediment samples varies from -68.5 to -96.2

$303 \%$ (mean $=-80.23 \%$, sd $=9.58, n=7)$ (Table 3). The values were more homogeneous in the

304 four water samples analysed with a mean $\delta^{13} \mathrm{C}$ of $-68.57 \%$ o (sd $\left.=1.34\right)$. Methane was the

305 main component of the hydrocarbon gas extracted from sediment (98.8 \%) and water (99.97

$306 \%)$.

307 The organic matter obtained in particle traps partly contained detritical matter from a 308 terrestrial origin (Treignier et al. 2006). Its $\delta^{13} \mathrm{C}$ value $(-23.22 \%$ ) is consistent with this 309 origin and with the $\delta^{13} \mathrm{C}$ value of sediments sampled off the cold-seep site (Table 4) while the $310 \delta^{15} \mathrm{~N}\left(4.43 \%\right.$ ) is lower due to less recycling. The $\delta^{13} \mathrm{C}$ of the sediment sampled next to the

311 different types of assemblages in the active site is depleted compared with these values and 312 on average is more depleted close to mytilid than vesicomyid clusters (Table 4). The 313 microorganism community, which probably contributes significantly to the carbon pool in the 314 sediment, may have a different composition depending on the site and environment

315 (Cambon-Bonavita et al., 2009) and thus a different signature. $\delta^{15} \mathrm{~N}$ values show a strong 316 contrast between mytilid and vesicomyid surrounding sediments. The values close to zero are 317 probably due to a higher contribution of the microbial primary producers compartment to the sediment close to the mytilids, where the methane fluxes are higher than close to vesicomyids

319 (Olu-Le Roy et al. 2007a), while the less depleted $\delta^{15} \mathrm{~N}$ values close to less active areas 320 colonised by vesicomyids may indicate a higher content of detrital/recycled material.

\subsubsection{Chemoautotrophic symbiont-containing species}

324 Bathymodiolus aff. boomerang tissues have quite homogeneous isotopic signatures and 325 demonstrated the most depleted values (Table 5), consistent with dominant nutrition via 
methanotrophic symbionts. Mussels from the M2 site are significantly more depleted in $\delta^{13} \mathrm{C}$,

327 particularly the gills (-67.05\%), than those from M1 and M3. Only at M2, have gills 328 significantly different $\delta^{13} \mathrm{C}$ than from the mantle.

329 The relative importance of methanotrophy vs. sulphide oxidation in the nutrition of the mussels can be estimated by a two-end-member mixing equation (Fry and Sherr, 1984) where:

$\delta^{13} C$ consumer $=f \times \delta^{13}$ Csource $1+(1-f) \times \delta^{13}$ Csource 2 (2) where $f$ is the proportion of carbon originated from source 1 in the nutrition of the consumer. or by Equation $(1): \delta x$ Epredator $-F=(\delta x$ Eseep $\times f)+(\delta x$ Eocean $\times(1-f))(1)$ already cited, taking into account the parameter $\mathrm{F}$ that corrects for trophic enrichment. We used $\mathrm{F}=1$ between carbon source and mussels, as isotopic fractionation is negligible during methanotrophy, from carbon source to the symbionts (Conway et al., 1994), and the two possible carbon sources are the $\mathrm{CH}_{4}$-derived carbon $\left(\delta^{13} \mathrm{C}=67-70 \%\right.$ ) and DIC $\left(\delta^{13} \mathrm{C}=23\right.$ \%). The estimated contribution of methanotrophy in the mussel nutrition is, following the Fry and Sherr equation (2), from 84 to $100 \%$ and following MacAvoy equation (1) from 85 to 88\%. Equation (2) was used by Van Dover et al. (2003) to estimate the relative importance of methanotrophy (source 1) vs. sulphide oxidation (source 2) in the nutrition of mussels, 343 assuming that photosynthetically derived material is negligible. Considering the methane signature as carbon source (1) and the vesicomyid signature for thiotrophically generated biomass as source (2), REGAB mytilids has a contribution of methanotrophy from 76 to 94\%. Vesicomyids showed typical values for sulphur-oxidizing symbionts, with no

347 significant differences between sites (V1/V3) or tissues. Escarpiids were characterised by more heterogeneous signatures, with significantly different values between sites with the less depleted at M1, dominated by mytilids, and the more for the adult bush EA. Juveniles 
sampled at EB had an intermediate isotopic signature, between those of adults from EA and

351

352

353

354

355

356

357

358

359

360

361

362

363

364

365

366

367

368

369

370

371

372

373

374 M1.

\subsubsection{Associate megafauna in chemosynthetic assemblages}

Results of the 55 individuals of 10 species of presumably non-symbiont-bearing invertebrates analysed for carbon and nitrogen stable isotopes are summarised in Table 6 and plotted in Figure 5. The tissue $\delta^{13} \mathrm{C}$ values of the species collected either during ROV dives in chemoautotrophic assemblages or by the trawl haul realised in the north part of the pockmark (CP20) ranged from -35.12 to $-60.09 \%$ and revealed that the major part of their diet is from a chemoautotrophic origin. Indeed, POM from particle traps has $\delta^{13} \mathrm{C}$ value of $-23.22 \%$ (Table 4). The sole exception is the galatheid Munidopsis hirtella $\left(\delta^{13} \mathrm{C}=-22.4 \%\right.$ ) only collected in the trawl, that is probably an occasional or vagrant species in the cold-seep site. The $\delta^{15} \mathrm{~N}$ values, ranging from 1.9 to $9.37 \%$, suggest that the majority of individuals derive their nutrition heterotrophically rather than from symbionts.

The isotopic signature of individuals collected by trawls in the north part of the pockmark ( $A$. muricola and Chiridota sp.) compared with those sampled by ROV in the central part of the pockmark showed a lesser contribution of chemosynthesis-based production in their diet (-20\%o shift in $\delta^{13} \mathrm{C}$ for the holothurid). The commensal polychaete Branchipolynoe sp. collected in Bathymodiolus mussels has a $\delta^{13} \mathrm{C}$ signature very close to its host. The grazers including the gastropods Provanna and Paralepetopsis, the shrimp A. muricola possessed depleted values of $-35.5 \%$ for Provanna, $-48.8 \%$ for the shrimps, and up to $-55.0 \%$ for the limpet specimens analysed, which suggests variable but a large contribution of bacteria in their diet, or different microbial communities with distinct signatures. $\delta^{15} \mathrm{~N}$ of 3.28 (Alvinocaris) to 3.89\% (Provanna) are consistent with a trophic regimen of primary consumers, probably mainly based on microbial communities, considering a shift of 3.5 to 
4\% between prey and predator and a signature of archaeal and bacterial populations between -1\%o (mytilid methanotroph symbionts) and 1\%o (vesicomyid sulphur-oxydising symbionts). beds suggest a main consumption of methanotrophic Archaes. The turrid gastropod Phymorrhynchus has the same $\delta^{13} \mathrm{C}$ signature as the vesicomyids, suggesting that bivalve tissues could partially be included in its diet. Phymorrhynchus has been observed in abundance among vesicomyid clusters. Nevertheless, its $\delta^{15} \mathrm{~N}$ values suggest another prey with a lighter signature. The echinoderms observed in the chemosynthetic assemblages such as Chiridota sp. or those close to them like the irregular echinoid, also have light $\delta^{13} \mathrm{C}$ values (respectively -57.1 and $-41.3 \%$ ). Their $\delta^{15} \mathrm{~N}$ values however differ, suggesting that echinids are primary consumers, probably grazing bacteria, while the holothurid has more enriched and more variable $\delta^{15} \mathrm{~N}$ values suggestive of more recycling material in its diet. This species also could partially feed on bivalve tissues from which they have an enrichment of about 4.04.5\% in $\delta^{15} \mathrm{~N}$. The detritivore/scavenger galatheids has nevertheless the most enriched $\delta^{15} \mathrm{~N}$ values (up to 9.7\%o), corresponding to a higher trophic level. Finally, the zoarcid fish

390 Lycodes sp. shows a quite variable signature in carbon (-25.4 to $-68.0 \%$ o) and nitrogen

391 (-1.23 to 9.4\%o), probably revealing a fairly variable diet; some individuals were observed

392 lying on bacterial mats while others are probably predators or scavengers of invertebrates.

393 Within some other species, especially A. muricola and Chiridota sp., $\delta^{13} \mathrm{C}$ and $\delta^{15} \mathrm{~N}$ values 394 vary according to the sampling site. Signatures of shrimps collected on mussel beds show 395 lighter values than those collected in vesicomyid clusters (Figure 6a). These shrimps which 396 have been observed grazing on bivalve mantles (Figure 6c) may have a nutritional link with 397 bivalves, characterised by different isotopic signatures. The more variable $\delta^{13} \mathrm{C}$ signature of 398 the shrimps at mytilid beds than at vesicomyid beds may also correspond to a higher 399 variability of microbe populations linked to methane- or sulphur-related processes. Similarly, 
a difference between habitats has been observed for the holothurid, with a correspondence 401 between $\delta^{13} \mathrm{C}$ values of the holothurid and of the dominant bivalves (mytild/vesicomyid)

402 (Figure 6b). This species, which has been observed among bivalves (Figure 6c), could be a 403 potential scavenger of bivalve tissues. Moreover, the very depleted value of its digestive wall $404\left(\delta^{13} \mathrm{C}=-66.71 \%\right.$ ) compared with the tegument or tentacles (respectively -53.9 and $-55.1 \%$ ) 405 may suggest the presence of bacteria in its digestive tract, although this was not seen by electronic microscope observations.

\subsubsection{Mobile megafauna collected by trawls}

409 Twelve benthic or benthopelagic fish species were sampled in the trawls located from the

410 REGAB site $14 \mathrm{~km}$ southward and northward. Some were collected only once or twice, 411 others such as the Acantaurus armatus (Ophidiidae) were present in most of the trawl 412 samples. Among the 11 species sampled close to the pockmark, 5 (Coryphaenoides striatus,

413 Stomias boa boa, Stylephorus chordatus, Bassozetus robustus and Porogadus milles) were 414 also collected at 4000-m sites and south of the Congo channel at $3000 \mathrm{~m}$ depth. The 415 Ophidiidae (A. armatus and B. robustus) were the most abundant in trawls in the close 416 vicinity of the seep area. Lycodes sp. (Zoarcidae) is the sole fish sampled only at the REGAB 417 site, where it was observed by ROV among bivalve assemblages. Despite a strong 418 heterogeneity in the isotopic signatures of the three specimens analysed, this species likely 419 has a high percentage of chemosynthesis-originated carbon in its diet (35-100\%) (Fig. 5, 420 Table 7).

421 Among the other fishes sampled in the trawl hauls closest to the active area (CP19-20-21), 422 the Ophidiidae B. robustus, A. armatus and Holomycteronus squamosus partially take 423 advantage of this local production with a mean contribution of chemosynthesis-originated 424 carbon from $15 \%$ for $A$. armatus to $38 \%$ for $H$. squamosus (Table 7). For some benthopelagic 
425 fishes, Scopeloberyx robustus (Melamphaidae) and Stylephorus chordatus (Stylephoridae),

426 the estimated percentage of chemosynthetic material is about $20 \%$. Specimens of Porogadus

427 milles showed variable signatures and the other species seem to be independent of the

428 chemosynthetic production. A decrease in the chemosynthetic contribution to the fish diet

429 with increasing distance from the pockmark was not observed, probably due to the large

430 distribution perimeter of these individuals.

431 The two species of galatheids greatly differ in the isotopic signatures of their tissues and,

432 therefore, by their dependence on the chemosynthetic production. Their distribution also

433 appears to be different according to their distribution in trawls and as only $M$. geyeri was

434 sampled during dives on REGAB.

435

436

4. Discussion

437

438

4.1. Level of dependence on chemosynthesis production

439

440 The distribution of the megafauna species along the dive tracks at the pockmark scale shows that the non-symbiont-bearing species, which are abundant within chemosynthetic assemblages (A. muricola, Chiridota sp.), are closely associated with symbiont-bearing species and as they are not, or rarely, observed outside the assemblages. Phymorrhynchus

444 and the galatheids are mainly located in the periphery of the chemosynthetic assemblages but 445 also do not have a regular distribution all over the pockmark, like fishes for example. 446 Although few species can be included in such analysis based on video processing, there is 447 evidence of the three levels of relationship, and possibly dependence, of the megafauna species relative to the seeps and chemoautotrophic processes, as defined by Carney (1994) as:

449 endemic, colonists and vagrant species. A. muricola and Chiridota sp. may be more 
dependent on the chemosynthetic production and may be endemic, whereas Phymorrhynchus

451

452

453

454

455

456

457

458

459

460

461

462

463

464

465

466

467

468

469

470

471

472

473

474

and the galatheids may be colonists of the seep ecosystem. Carbon isotopic signatures of these two species are, moreover, less depleted than other heterotrophs sampled in the assemblages; this seems to confirm a lesser degree of chemosynthetic dependence than for $A$. muricola or Chiridota sp.. The small gastropods Provanna and Paralepetopsis, whose distribution of the chemosynthetic assemblages could not be estimated using video transects, are also probably strongly dependent on seep processes, judging from to their $\delta^{13} \mathrm{C}$ values. These two species were also abundant in chemosynthesis assemblages in the central active part of the pockmark (mytilid and vesicomyid beds, adult escarpiid bushes), but absent in the vesicomyid clusters located at the periphery of the pockmark, which was less active in terms of fluid emission.

\subsection{Trophic guilds and contribution to the biomass}

Biomass of megafauna in chemosynthetic assemblages of the REGAB site is dominated by symbiont-bearing species. With the exception of E. southwardae which presents variability already observed for the Siboglinidae polychaetes (Conway et al., 1994; MacAvoy et al., 2005); all the other symbiont hosts have a homogeneous isotopic signature. The variability of the carbon isotopic signature according to the different sites, could be related to the use of different DIC sources (which might reflect different carbon signatures), to methane concentration and to the age of the tubeworm. However, at the well-studied Gulf of Mexico seeps, no differences between old and young tube-worm aggregations were observed for Lamellibrachia luymesi (-20\%) and Seepiophyla jonesi (-22\%o) (MacAvoy et al., 2005). The mytilid Bathymodiolus sp. aff. boomerang possesses both methanotrophic and sulphuroxidising symbionts (Duperron et al., 2005), but at the sites sampled for this study the carbon 
475 isotopic signature of their tissues is very close to that of methane and mainly derives its 476 carbon from methanotrophy according to the mixing equations applied to our stable isotope 477 measurements. The most depleted $\delta^{13} \mathrm{C}$ values, suggesting a higher contribution of 478 methanotrophic symbionts, originated from the M2 site mytilids where the highest methane 479 concentrations were recorded. This situation is closer to that of mussels in the Gulf of Mexico 480 seeps that have only methanotrophic symbionts (Brooks et al., 1987) than that of the Blake 481 ridge mussels Bathymodiolus heckerae, which, like REGAB mytilids, harbour two types of symbionts (Van Dover et al., 2003). The vesicomyids and E. southwardae harbour only sulphur-oxidising bacteria (Nadalig et al., in press). After symbiont-bearing species, the second contributor to the biomass is the shrimp A. muricola, representing up to $10 \%$ of the 485 total dry weight of mytilid and vesicomyid clusters (M1, VC), and $25 \%$ in the tube-worm 486 aggregations. Densities reach 450ind. $\mathrm{m}^{-2}$ in mussel beds. In contrast, they show low densities in some vesicomyid clusters of peripheral areas (V1, Vext). According to its nitrogen isotopic signature, the shrimp seems to be mainly a primary consumer. Similarly, in the Gulf of Mexico seeps, Alvinocaris stactophila was one of the most abundant species associated with mussel beds, accounting for up to $17 \%$ of the individuals collected, apart from mussels, and this species being related to the higher methane concentrations (Bergquist et al., 2005), which is consistent with our observations. Other primary consumers mainly relying on microbial biomass (Provanna., Paralepetopsis) may have very high densities, equivalent to those of 494 shrimps in most of the bivalves clusters, and sometimes higher (at M1); however the biomass 495 is much less owing to their small size. Quantitative sampling could, nevertheless, give 496 slightly different results, with image analysis biased toward the larger species. Small 497 gastropods are also the most abundant species in Gulf of Mexico mussel beds, with Provanna 498 sculpta accounting for up to 14\% of the individuals (Bergquist et al. 2005). Echinids are not included in density/biomass estimation as they are mainly located in the vicinity of the 
chemosynthetic assemblages. Nevertheless, they are abundant in soft sediment areas close to

501 vesicomyid beds and are another species that seem to be mainly primary consumers of

502 microbial chemoautotrophic communities.

503 Higher trophic levels including the holothurid, galatheids and zoarcid fish are not very 504 abundant in the sampled assemblages, except locally for Chiridota sp. in bivalve beds (93 505 ind. $\mathrm{m}^{-2}$ and $5 \%$ of the biomass in V3), which could be a scavenger of both vesicomyids and mussels. The density and biomass of these higher trophic levels (detritivorous, scavengers, predators) increase with the proportion of empty shells in vesicomyid clusters, $M$. geyeri and Phymorrhynchus in V1, Chiridota (11 ind $\left./ \mathrm{m}^{2}\right)$, Phymorrhynchus and M. geyeri in VB. At the pockmark scale, distribution based on transects show that holothurids and galatheids are quite

510 abundant in the area colonised by chemosynthesis-based communities (Fig. 3). Galatheids

511 belonging to the genus Munidopsis have been reported to be dependent on chemosynthetic

512 production at deep seeps (Levin and Michener, 2002) and to feed on vesicomyid clams

513 (Sahling et al., 2003). At the REGAB site their $\delta^{15} \mathrm{~N}$ signature suggests a diet mainly based

514 on recycled material. Low predation pressure in living chemosynthetic assemblages has been

515 suggested at deep cold-seep sites compared with shallower sites (Sahling et al. 2003).

516 Nevertheless, Phymorrhynchus observed in abundance in some vesicomyid clusters,

517 particularly in the periphery areas, may not only be a scavenger but also an active predator

518 (A. Warén, pers. com.).

519 The primary "consumers", via endosymbioses with chemoautotrophic bacteria, or mainly 520 grazing on free-living microbial communities, therefore dominate the chemosynthetic assemblages in the active centre of the pockmark. There are some possible predators/scavengers, but their densities and biomass are low, at least in the assemblages sampled for this study. In the periphery, the low-density vesicomyid clusters with a high

524 proportion of empty shells provide detritical material for detritivores and scavengers, and 
525 higher trophic levels dominate the heterotrophic fauna. Such a community structure, with a 526 clear dominance of primary consumers, symbiont hosts and bacterivores, has been observed 527 from quantitative sampling in the hydrothermal vent community dominated by the siboglinid 528 Ridgeia piscesae (Bergquist et al., 2007). The commensal Polynoidae Branchipolynoe sp. has 529 been found in most of the mussels collected on REGAB but the sampling effort is not 530 sufficient to estimate its abundance, and it could represent a non-negligible part of the biomass. As observed in other hydrothermal vent and cold-seep sites, its isotopic signature suggests a strong nutritional relationship with its host (Colaço et al., 2002; Fisher et al., 1994; Suzuki et al., 1989; Van Dover et al., 2003). According to Desbruyères et al. (1985) from gut content analyses, commensal polynoids nutrition is based on mussel mucus-rich pseudofaeces and gills. More generally, the polychaete community that is not included in this study, likely play an important role in the community structure and could contribute to the biomass of predators, as has been shown in hydrothermal vent communities for polynoids in particular (Bergquist et al. 2007). At seeps, the Amphinomid polychaete has been suggested to obtain significant dietary carbon directly from the symbiont-containing Bathymodiolus childressi

540 (MacAvoy et al. 2005).

541 Finally, biomass of associated species is highest in mytilid beds and more variable in vesicomyid clusters, mostly due to the presence or absence of only one species Chiridota sp. Nevertheless, the infauna that are not included in this study probably contribute more to the

544 biomass than in the case of mytilid and siboglinids.

\subsection{Transfer of seep organic matter to the surrounding ecosystem}

The mobile benthic predators/scavengers that use chemosynthetic biomass may contribute to the export of seep organic production to the surrounding ecosystem. Isotopic measurements suggest that the contribution of chemosynthetic material in fish diet is variable among the 
species but not negligible (more than 15\% and up to 38\%) for 5 of the species captured off the cold-seep site among the 12 analysed. These species have been sampled at least in the northern part of the cold-seep site (CP20) or in a 100-m radius around the pockmark and some (Ophidiidae) have been observed during ROV dives. Only the Zoarcidae Lycodes sp. is resident in the seeps, and may be endemic, according to its high degree of dependence from chemosynthetic production and their absence in trawl samples outside the seep site. The two species of galatheids differ greatly in the isotopic signatures of their tissues and, therefore, by their dependence on the chemosynthetic production. Their distribution also appears to be different according to their distribution in trawls and as only $M$. geyeri was sampled during dives on REGAB.

561 In comparison, a similar study in the shallower sites of the Gulf of Mexico (MacAvoy et al. 2002) showed several species of fish and invertebrates that obtained between 50 and $100 \%$ of their nutrition from seep production, indicating that they are resident to the seeps. There is also a greater abundance of vagrants at bathyal depths than at $3200 \mathrm{~m}$ depth. MacAvoy et al. indicated that several vagrant predators/scavengers sampled on seep sites, including fishes (Nezumia sp., Oligopus sp., and the eels Synaphobranchus sp., Ophicthus cruentifer and Dysomma rugosa) and three invertebrates (Bathynomus giganteus, Buccinum canetae, Scleracterias tanneri) have a significant contribution of chemosynthetic material in their diet. Predation by large and mobile species of seep resident species is probably much higher at these shallow sites, because the surrounding benthos is probably more depauperate, as suggested by Sahling et al. (2003) in the Sea of Okhotsk. However, all these species were captured on the Louisiana slope cold-seep sites whereas those collected off-site by traps (2 $\mathrm{km}$ from the location of the seep communities) used from 0 to $40 \%$ of chemosynthetic material, which is not different from our study. 
The chemosynthetic assemblages of the REGAB site share many genera and even species with other cold-seep sites in the Atlantic. The alvinocarid shrimp Alvinocaris muricola has been collected in the Gulf of Mexico (Carney, 1994; Cordes et al., 2007), Blake Ridge (Van Dover et al. 2003) and Barbados seep aggregations (Olu et al., 1996), and the chirodotid holothurian Chiridota heveva, which seems to be very close to the REGAB species, was first described from the Blake Ridge mussel beds (Pawson and Vance, 2004). The gastropod Provanna sculpta is abundant within Gulf of Mexico mussel beds (Bergquist et al., 2005) and tube-worm aggregations (Bergquist et al., 2003). Actinians have also been reported in Blake Ridge mussel beds and from the Florida escarpment (Cordes et al., 2007; Van Dover et al., 2003). Galatheid crabs Munidopsis sp. are generally associated. The commensal polynoid Branchipolynoe seepensis may also be a common species to West Atlantic and East Atlantic cold-seep mussels (Desbruyères and Hourdez, unpubl.) The community inhabiting the REGAB pockmark is very similar to the group of communities described for the deep seeps of the Gulf of Mexico (2200-3300 m), the intermediate-depth sites of the Barbados prism (1700-2000) and the $2150 \mathrm{~m}$ Blake Ridge sites, which have been included in the same group, clustered by depth instead of geography by Cordes et al. (2007). Indeed this 'deep' seep community from the western Atlantic includes E. laminata and B. heckerae or B. boomerang as structuring species, and A. muricola, Munidopsis sp., B. seepensis, Chiridota sp., Phymorrhynchus sp. a Nautillinellid polychaete and the ophiurid Ophioctenella acies. Except for these last two species, all the other species or genera have been sampled on REGAB. Most intriguing is the co-occurrence of similar species from both sides of the Atlantic, that has been discussed for Bathymodiolus boomerang (Olu-Le Roy et al. 2007b) as example of 600 two amphi-atlantic Bathymodiolinae species complexes, Alvinocharid shrimps (Komai and 
601 Segonzac 2005), and more generally by Cordes et al. (2007) comparing associated fauna

602 from box core sampling on the Nigerian margin and cold-seep communities from the Eastern

603 Atlantic.

604

605 5. Conclusion

606 The REGAB pockmark cold-seep community is the first to be described in the Equatorial

607 East Atlantic and the second in the Eastern Atlantic after the Haakon Mosby Mud Volcano 608 located in high latitudes (Gebruk et al. 2003). REGAB's striking feature is the abundance and 609 diversity of large symbiont-bearing species, mytilid and vesicomyid bivalves and siboglinids, 610 forming puzzling habitats hosting chemosynthetic assemblages, whose highest biomasses are

611 found in the mussel beds likely located in the highest fluid flow areas. Associated megafauna

612 is very similar among assemblage types, with few same dominant taxa but whose individuals

613 may be closely associated with local aggregates as suggested by the variation of isotopic

614 signatures according to the types of aggregates or habitat. These associate species, which are

615 likely endemics of the seep community, mainly use chemosynthesis-derived carbon but with

616 variable contribution of methanotrophy or thiotrophy. Biomass in the sampled assemblages

617 was dominated by primary "consumers", either symbiont-bearing species or feeders of free

618 living microbes, such as shrimps or gastropods. Scavengers (galatheids, probably

619 holothurids) and possible predators (Phymorhynchus and zoarcid fishes) representing the

620 higher trophic levels are less dense distributed but occur all over the area colonised by

621 chemosynthetic assemblages. Export of local production by colonists or vagrant species is

622 reduced compared to shallower depth seeps but has been shown for 7 species of fish with

623 more than $10 \%$ contribution of chemosynthesis-based carbon and for two galatheids. The

624 REGAB community bears a high resemblance to those associated with seeps in the western

625 Atlantic (Barbados prism, Gulf of Mexico, Blake Ridge). Further sampling efforts using 
quantitative tools are necessary to describe better the communities associated with each of the three chemosynthetic assemblages, and for comparison with studies on similar habitats in the Gulf of Mexico seeps. The REGAB pockmark is an unusual cold-seep site by the high spatial heterogeneity of habitats in a relatively restricted area, which makes comparisons easier between habitats and chemosynthetic assemblages. Thus it is possible to identify the factors controlling the community structure without the influence of factors that may play a role in a broader scale, such as bathymetry, geology of the structures, or biogeography.

633

634

635

636

Acknowledgements

637

The BIOZAIRE program was partially funded by TOTAL (P.I. M. Sibuet for Ifremer). We are grateful to the chief scientists of the BIOZAIRE 1, 2 and 3 cruises (M. Sibuet, A. Khrippounoff), and to the captains and the crews of the N.O. L'Atalante and VICTOR 6000 team. We are indebted to A. Fifis who processed the samples processing during the BIOZAIRE 2 cruise and M.-C. Fabri for her useful help particularly for the database management (BIOCEAN). All our colleagues on the Biozaire 2 and 3 cruises are thanked for their help onboard. A. Le Goff and A. Bousquet contributed to sample processing. A. Warén is thanked for discussions about nutritional strategies of gastropods. We are indebted to the anonymous reviewers for their helpful comments and suggestions to improve the manuscript.

We are grateful to Myriam Sibuet and Annick Vangriesheim for the co-edition of this special issue on the Biozaire program. This work contributes to the Census of Marine Life project COMARGE (Continental Margin Ecosystems on a worldwide scale). 
Barry, J.P., Kochevar, R.E., Baxter, C.H., 1997. The influence of pore-water chemistry and physiology in the distribution of vesicomyid clams at cold seeps in Monterey Bay : implications for patterns of chemosynthetic community organization. Limnology and Oceanography 42 (2), 318-328.

Bergquist, D.C., Eckner, J.T., Urcuyo, I.A., Cordes, E.E., Hourdez, S., Macko, S.A., Fisher, C.R., 2007. Using stable isotopes and quantitative community characteristics to determine a local hydrothermal vent food web. Marine Ecology Progress Series 330, 49-65.

Bergquist, D.C., Fleckenstein, C., Knisel, J., Begley, B., MacDonald, I.R., Fisher, C.R., 2005. Variations in seep mussel bed communities along physical and chemical environmental gradients. Marine Ecology Progress Series 293, 99-108.

Bergquist, D.C., Ward, T., Cordes, E.E., McNelis, T., Howlett, S., Kosoff, R., Hourdez, S., Carney, R., Fisher, C.R., 2003. Community structure of vestimentiferan-generated habitat islands from Gulf of Mexico cold seeps. Journal of Experimental Marine Biology and Ecology 289, 197-222.

Brooks, J.M., Kennicutt II, M.C., Fisher, C.R., Macko, S.A., Cole, K., Childress, J.J., Bidigare, R.R., Vetter, R.D., 1987. Deep-sea hydrocarbon seep communities: Evidence for energy and nutritional carbon sources. Science 238, 1138-1142.

Cambon Bonavita, M., Nadalig, T., Roussel, E., Delage, E., Duperron, S., Caprais, J.C., Boetius, A., Sibuet, M., 2009. Distribution of AOM aggreagates and microbial diversity associated to different faunal assemblages in a giant pockmarck of Gabon continental margin. Deep Sea Research II (this volume).

Carney, R.S., 1994. Consideration of the oasis analogy for chemosynthetic communities at Gulf of Mexico hydrocarbon vents. Geo-Marine Letters 14, 149-159.

Charlou, J.L., Donval, J.P., Fouquet, Y., Ondreas, H., Knoery, J., Cochonat, P., Levache, D., Poirier, Y., Jean-Baptiste, P., Fourre, E., 2004. Physical and chemical characterization of gas hydrates and associated methane plumes in the Congo-Angola Basin. Chemical Geology 205 (3-4), 405.

Colaço, A., Dehairs, F., Desbruyères, D., 2002. Nutritional relations of deep-sea hydrothermal fields at the Mid-Atlantic Ridge: a stable isotope approach. Deep-Sea Research 49, 395-412.

Conway, N.M., Kennicutt, M.C., Van Dover, C.L., 1994. Stable isotopes in the study of marine chemosynthetic-based ecosystems. Blackwell scientific publications, London.

Cordes, E.E., Carney, S.L., Hourdez, S., Carney, R.S., Brooks, J.M., Fisher, C.R., 2007. Cold seeps of the deep Gulf of Mexico: Community structure and biogeographic comparisons to Atlantic equatorial belt seep communities. Deep Sea Research Part I: Oceanographic Research Papers 54 (4), 637-653.

Cordes, E.E., Hourdez, S., Predmore, B.L., Redding, M.L., Fisher, C.R., 2005. Succession of hydrocarbon seep communities associated with the long-lived foundation species Lamellibrachia luymesi. Marine Ecology Progress Series 305, 17-29.

Cosel, R.von, Olu, K., 2008. A new genus and new species of Vesicomyidae (Mollusca: Bivalvia) from cold seeps on the Barbados accretionary prism, with comments on other species. Zoostystema 30 (4): 929-944 
Cosel, R.von, Olu, K., in press. Large Vesicomyidae (Mollusca: Bivalvia) from cold seeps in the Gulf of Guinea off the coasts of Gabon, Congo and northern Angola. Deep Sea Research II (this volume).

Desbruyères, D., Gaill, F., Laubier, L., Fouquet, Y., 1985. Polychaetous annelids from hydrothermal vent ecosystems: An ecological overview. Bull. Biol. Soc. Wash. 6, 103116.

Duperron, S., Nadalig, T., Caprais, J.C., Sibuet, M., Fiala-Médioni, A., Amann, R., Dubilier, N., 2005. Dual symbiosis in a Bathymodiolus sp mussel from a methane seep on the gabon continental margin (southeast Atlantic): 16S rRNA phylogeny and distribution of the symbionts in gills. Applied and Environmental Microbiology 71 (4), 1694-1700.

Fisher, C.R., Childress, J.J., Macko, S.A., Brooks, J.M., 1994. Nutritional interactions in Galapagos Rift hydrothermal vent communites: inferences from stable carbon and nitrogen isotope analyses. Marine Ecology Progress Series 103, 45-55.

Fry, B., Sherr, E.B., 1984. d13C measurements as indicators of carbon flow in marine and freshwater ecosystems. Contributions in Marine Science 27, 13-47.

Gebruk, A., Krylova, E.M., Lein, A., Vinogradov, G.M., Anderson, E., Pimenov, N.V., Cherkashev, G.A., Crane, K., 2003. Methane seep community of the Hakon Mosby mud volcano the Norwegian Sea: composition and trophic aspects. Sarsia 88 (6), 394-403.

Henry, P., Foucher, J.P., Le Pichon, X., Sibuet, M., Kobayashi, K., Tarits, P., Chamot-Rooke, N., Furuta, T., Schultheiss, P., 1992. Interpretation of temperature measurements from the Kaiko-Nankai cruise: Modeling of fluid flow in clam colonies. Earth and Planetary Science Letters 109, 355-371.

Kennicutt II, M.C., Burke Jr., R.A., Mac Donald, I.R., Brooks, J.M., Denoux, G.J., Macko, S.A., 1992. Stable isotope partitioning in seep and vent organisms: chemical and ecological significance. Chemical Geology (Isotope Geosciences Section) 101, 293-310.

Komai, T., Segonzac, M., 2005. A revision of the genus Alvinocaris Williams and Chace (Crustacea: Decapoda: Caridea: Alvinocaridea), with descriptions of a new genus and a new species of Alvinocaris. Journal of Natural History 39 (15), 1111-1175.

Levesque, C., Juniper, K., Marcus, J., 2003. Food resource partitioning and competition among alvinellid polychaetes of Juan de Fuca Ridge hydrothermal vents. Marine Ecology Progress Series 246, 173-182.

Levesque, C., Kim Juniper, S., Limen, H., 2006. Spatial organization of food webs along habitat gradients at deep-sea hydrothermal vents on Axial Volcano, Northeast Pacific. Deep Sea Research Part I: Oceanographic Research Papers In Press, Corrected Proof.

Levin, L.A., 2005. Ecology of cold seep sediments: interactions of fauna with flow, chemistry and microbes. Oceanography and Marine Biology Annual Review 43, 1-46.

Levin, L.A., James, D.W., Martin, C.M., Rathburn, A., Harris, L., Michener, R., 2000. Do methane seeps support distinct infaunal assemblages? Observations on community structure and nutrition from the northern California slope and shelf. Marine Ecology Progress Series 208, 21-39.

Levin, L.A., Michener, H.M., 2002. Isotopic evidence for chemosynthesis-based nutrition of macrobenthos: The ligntness of being at Pacific methane seeps. Limnology and Oceanography 47 (5), 1336-1345. 
Levin, L.A., Ziebis, W., Mendoza, G.F., Growney, V.A., Tryon, M.D., Mahn, C., Gieskes, J.M., Rathburn, A.E., 2003. Spatial heterogeneity of macrofauna at northern California methane seeps: influence of sulfide concentration and fluid flow. MEPS 265, 123-139.

MacAvoy, S.E., Carney, R.S., Fisher, C.R., Macko, S.A., 2002. Use of chemosynthetic biomass by large, mobile, benthic predators in the Gulf of Mexico. Marine Ecology Progress Series 225, 65-78.

MacAvoy, S.E., Fisher, C.R., Carney, R.S., Macko, S.A., 2005. Nutritional associations among fauna at hydrocarbon seep communities in the Gulf of Mexico. Marine Ecology Progress Series 292, 51-60.

MacDonald, I.R., Sager, W.W., Peccini, M.B., 2003. Gas hydrate and chemosynthetic biota in mounded bathymetry at mid-slope hydrocarbon seeps: Northern Gulf of Mexico. Marine Geology 198, 133-158.

Macpherson, E., Segonzac, M., 2005. Species of the genus Munidopsis (Crustacea, Decapoda, Galatheidae) from the deep Atlantic Ocean, including cold-seep and hydrothermal vent areas. Zootaxa, 1-60.

Micheli, F., Peterson, C.H., Mullineaux, L.S., Fisher, C.R., Mills, S., Sancho, G., Johnson, G.A., Lenihan, H.S., 2002. Predation structures communities at deep-sea hydrothermal vents. Ecological Monographs 72, 365-382.

Minegawa, M., Wada, E., 1984. Stepwise enrichment of $15 \mathrm{~N}$ along food chains: further evidence and the relation between $15 \mathrm{~N}$ and animal age. Geochimical and Cosmochimical Acta 48, 1135-1140.

Olu-Le Roy, K., Caprais, J.C., Fifis , A., Fabri , M.C., Galéron, J., Budzinski, H., Le Ménach, K., Khripounoff, A., Ondréas, H., Sibuet, M., 2007a. Cold seep assemblages on a giant pockmark off West Africa: spatial patterns and environmental control. Marine Ecology 28, 115-130.

Olu-Le Roy, K., Cosel, R.v., Hourdez, S., Carney, S.L., Jollivet, D., 2007b. Amphi-Atlantic cold-seep Bathymodiolus species complexes across the equatorial belt. Deep Sea Research Part I: Oceanographic Research Papers 54 (11), 1890-1911.

Olu - Le Roy, K., Le Goff, A., Fifis, A., Caprais, J.C., Budzinsky , H., Le Ménach, K., Khripounoff, A., Sibuet, M., in prep. Community structure and nutritional patterns of megafauna assemblages on a giant pockmark in the Gulf of Guinea.

Olu, K., Lance, F., Sibuet, M., Henry, P., Fiala-Médioni, A., Dinet, A., 1997. Cold seep communities as indicators of fluid expulsion patterns through mud volcanoes seaward of the Barbados accretionary prism. Deep-Sea Research I 44 (5), 811-841.

Olu, K., Sibuet, M., Harmegnies, F., Foucher, J.-P., Fiala-Medioni, A., 1996. Spatial distribution of diverse cold seep communities living on various diapiric structures of the southern Barbados prism. Progress in Oceanography 38, 347-376.

Ondréas, H., Olu, K., Fouquet, Y., Charlou, J., Gay, A., Dennielou, B., Donval, J., Fifis, A., Nadalig, T., Cochonat, P., Cauquil, E., Bourillet, J., Moigne, M., Sibuet, M., 2005. ROV study of a giant pockmark on the Gabon continental margin. Geo-Marine Letters 25 (5), 281.

Paull, C.K., Hecker, B., Commeau, R., Freeman-Lynde, R.P., Neumann, C., Corso, W.P., Golubic, S., Hook, J.E., Sikes, E., Curray, J., 1984. Biological communities at the Florida escarpment resemble hydrothermal vent taxa. Science 226, 965-967. 
Paull, C.K., Jull, A.J.T., Toolin, L.J., Linick, T., 1985. Stable isotope evidence for chemosynthesis in an abyssal seep community. Nature, pp. 709-711.

Pawson, D.L., Vance, D.J., 2004. Chirodota heheva, new species, from Western Atlantic deep-sea cold seeps and anthropogenic habitats (Echinodermata: Holothuroidea: Apodida). Zootaxa 534, 1-12.

Polz, M.F., Robinson, J.J., Cavanaugh, C.M., Van Dover, C.L., 1998. Trophic ecology of massive shrimp aggregations at a Mid-Atlantic Ridge hydrothermal vent site. Limnology and Oceanography 43 (7), 1631-1638.

Rau, G.H., Hedges, J.I., 1979. Carbon-13 depletion in a hydrothermal vent mussel: suggestion of a chemosynthetic food source. Science 203, 648-649.

Rau, G.H., Mearns, A.J., Young, D.R., Olsen, R.J., Schafer, H.A., Kaplan, I.R., 1983. Animal 13C/12C correlates with trophic levels in pelagic food webs. Ecology 64, 1314-1318.

Sahling, H., Galkin, S.V., Salyuk, A., Greinert, J., Foerstel, H., Piepenburg, D., Suess, E., 2003. Depth-related structure and ecological significance of cold-seep communities--a case study from the Sea of Okhotsk. Deep Sea Research Part I: Oceanographic Research Papers 50 (12), 1391-1409.

Sahling, H., Rickert, D., Lee, R.W., Linke, P., Suess, E., 2002. Macrofaunal community structure and sulfide flux at gas hydrate deposits from the Cascadia convergent margin, NE Pacific. Marine Ecology Progress Series 231, 121-138.

Sarrazin, J., Juniper, K., 1999. Biological characteristics of a hydrothermal edifice mosaic community. Marine Ecology Progress Series 185, 1-19.

Sarrazin, J., Juniper, S.K., Massoth, G., Legendre, P., 1999. Physical and Chemical factors influencing species distributions on hydrothermal sulfide edifices of the Juan de Fuca Ridge, Northeast Pacific. Marine Ecology Progress Series 190, 89-112.

Sibuet, M., Olu-Le Roy, K., 2002. Cold Seep Communities on Continental Margins: Structure and Quantitative Distribution Relative to Geological and Fluid Venting Patterns. In: G. Wefer, D.B., D. Hebbeln, B.B. Jorgensen, T. Van Weering (Ed.), Ocean Margin Systems. Springer Verlag, Berlin, pp. 235-251.

Sibuet, M., Olu, K., 1998. Biogeography, biodiversity and fluid dependence of deep-sea coldseep communities at active and passive margins. Deep-Sea Research II 45, 517-567.

Sibuet M, Vangriesheim A (2009) Deep-Sea Environment and Biodiversity of the West African Equatorial margin. Deep Sea Research II this volume

Suzuki, T., Takagi, T., Ohta, S., 1989. Primary structure of a dimeric haemoglobin from the deep-sea cold-seep clam Calyptogena soyoae. Biochemical Journal 260, 177-182.

Thiele, J., Jaeckel, S., 1931. Muscheln der Deutschen Tiefsee-Expedition. Wissenschaftliche Ergebnisse der Deutschen Tiefsee-Expedition auf dem Dampfer "Valdivia" 21(1), 159268, 5 pls: Gustav Fischer, Jena.

Tunnicliffe, V., 1991. The biology of hydrothermal vents : ecology and evolution. In: Barnes, M. (Ed.), Oceanogr. Mar. Biol. Annu. Rev. Aberdeen University Press, pp. 319-407.

Van Dover, C., Aharon, P., Bernhard, J.M., Caylor, E., Doerries, M., Flickinger, W., Gilhooly, W., Goffredi, S.K., Knick, K., Macko, S.A., Rapoport, S., Raulfs, E.C., Ruppel, C., Salerno, J., Seitz, R.D., Sen Gupta, B.K., Shank, T., Turneipseed, M., Vrijenhoek, R.C., 2003. Blake Ridge methane seep: characterization of a soft-sediment, chemosynthetically based ecosystem. Deep-Sea Research I 50, 281-300. 
855

856 857 858

Van Dover, C.L., 1995. Ecology of Mid-Atlantic Ridge hydrothermal vents. In: Parson, L.M., Walker, C.L., Dixon, D.R. (Eds.), Hydrothermal vents and processes. Geological Society Special Publication, London, pp. 257-294.

Van Dover, C.L., 2002. Trophic relationships among invertebrates at the Karei hydrothermal vent field (Central Indian Ridge). Marine Biology 141, 761-772.

Van Dover, C.L., Fry, B., 1989. Stable isotopic compositions of hydrothermal vent organisms. Marine Biology 102, 257-263.

Vereshchaka, A.L., Vinogradov, G.M., Lein, A.Y., Dalton, S., Dehairs, F., 2000. Carbon and nitrogen isotopic composition of the fauna from the Broken Spur hydrothermal vent field. Marine Biology 136, 11-17.

Warén, A., Bouchet, P., in press. New gastropods from deep-sea hydrocarbon seeps off West Africa. Deep Sea Research II.

Table and figure caption

Table 1: Characteristics of the sampling sites based on dominant symbiont-bearing species. Abbreviations: Mx: site dominated by Mytilidae; Vx: by Vesicomyidae, E: by Escarpiidae. For the location, see Fig.2b.

Table 2: Densities (ind. $\mathrm{m}^{-2}$ ) (a) and biomass (g dry weight.m²) (b) of megafauna species from image analysis and sampling in the clusters defined by symbiont bearing species (M: clusters dominated by mytilids; V: by vesicomyids, E: by escarpiids). n.e.: non estimated

Table 3: Isotopic carbon signature $\left(\delta^{13} \mathrm{C}\right)$ of methane extracted from sediment or expelled fluid on the REGAB pockmark. Percentage of methane in the total gas fraction is calculated from gas chromatography peak integration.

Table 4: Isotopic signatures of sediment and particles sampled by cores or traps in and off the REGAB pockmark.

Table 5: Isotopic signatures of symbiont-bearing species from different sampling sites in the REGAB pockmark. 
Table 6: Mean isotopic signatures of associated megafauna sampled by ROV in the clusters dominated either by mytilids (M), vesicomyids (V) or escarppids (E) or by trawl (CP20) in the REGAB cold-seep site.

Table 7: Isotopic signature $\left(\delta^{13} \mathrm{C}\right)$ of fishes sampled by trawls at increasing distance from the REGAB site and estimated percentages of chemosynthetic material in their diet. See fig. 1 for the localization of trawls.

Figure 1: Location of the REGAB pockmark along the Congo-Angola margin and of the benthic trawls

Figure 2:a. Location of the dive tracks in the REGAB site, analyzed for megafauna distribution, and of sampling sites. Two dive tracks are represented by the black and grey lines; the box indicates the area surveyed by five more dives. b. Distribution of chemosynthetic assemblages along the dive tracks, classified by the dominance of symbiotic species (from Olu-Le Roy et al. 2007a).

Figure 3: Distribution maps of major associated megafauna species along the dive tracks. a. Chiridota sp., b. Munidopsis sp., c. Alvinocaris muricola, d. Irregular echinid.

Figure 4: Multidimentional scaling (MDS) plots of the species/biotope matrix of distance using the Bray Curtis distance (Primer software). a. Similarity between biotopes, $\mathbf{b}$. Similarity between species. $\mathrm{H}=$ hydrate outcrop, B=gas bubbles, BM=bacterial mat, Conc=carbonate concretion, $\mathrm{S}=$ soft sediment, RS=reduced sediment, Ed=dead escarpiids, El=live escarpiids, $\mathrm{M}=$ =mytilids, $\mathrm{Vd}=\mathrm{dead}$ vesicomyids, $\mathrm{Vl}=$ live vesicomyids, $\mathrm{Vm}=$ mixed (live and dead) vesicomyids.

Figure 5: Mean $\delta^{13} \mathrm{C}$ vs $\delta^{15} \mathrm{~N}$ values of each species, sediment samples or particles analysed from the REGAB pockmark. The signatures of the three Zoarcidae fish are represented to show the high variability between specimens. Methane $\delta^{13} \mathrm{C}$ values are also plotted. CI to CIII correspond to the different levels of consumers (from primary to tertiary) 
892 Figure 6: $\delta^{13} \mathrm{C}$ vs $\delta^{15} \mathrm{~N}$ values of shrimps Alvinocaris muricola (a) and holothurids Chiridota 893 sp. (b) from different sites dominated either by mytilids (M) or vesicomyids (V) with signature of the bivalves at the different sampling sites and sediment for holothurids.(c) from left to right: A. muricola among mussels, Chiridota sp. in mussel and vesicomyid aggregates.

897 


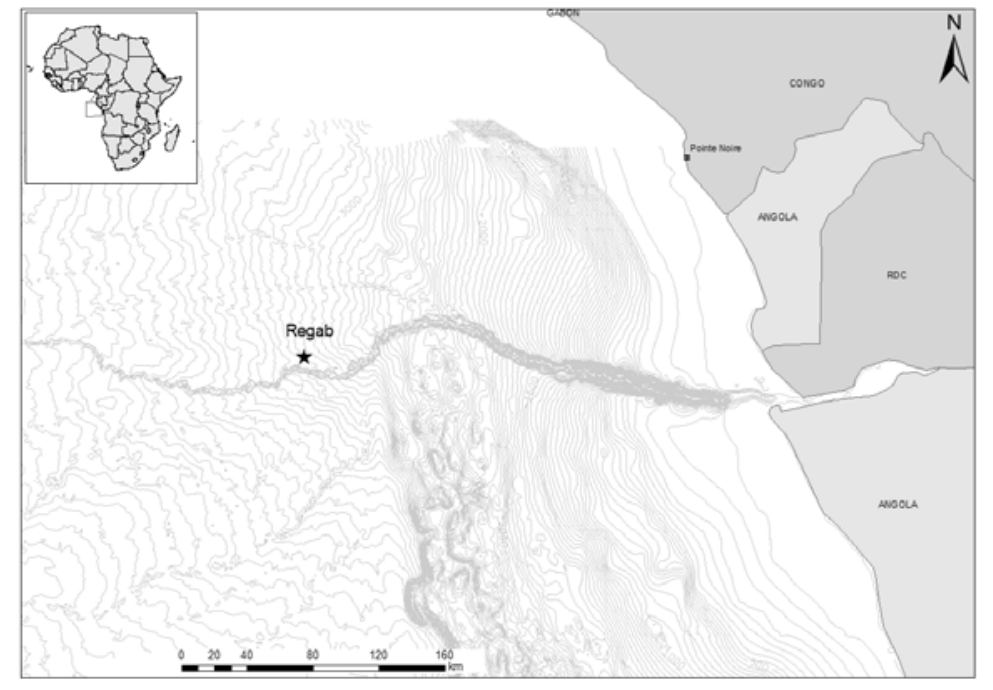

Fig. 1

a.

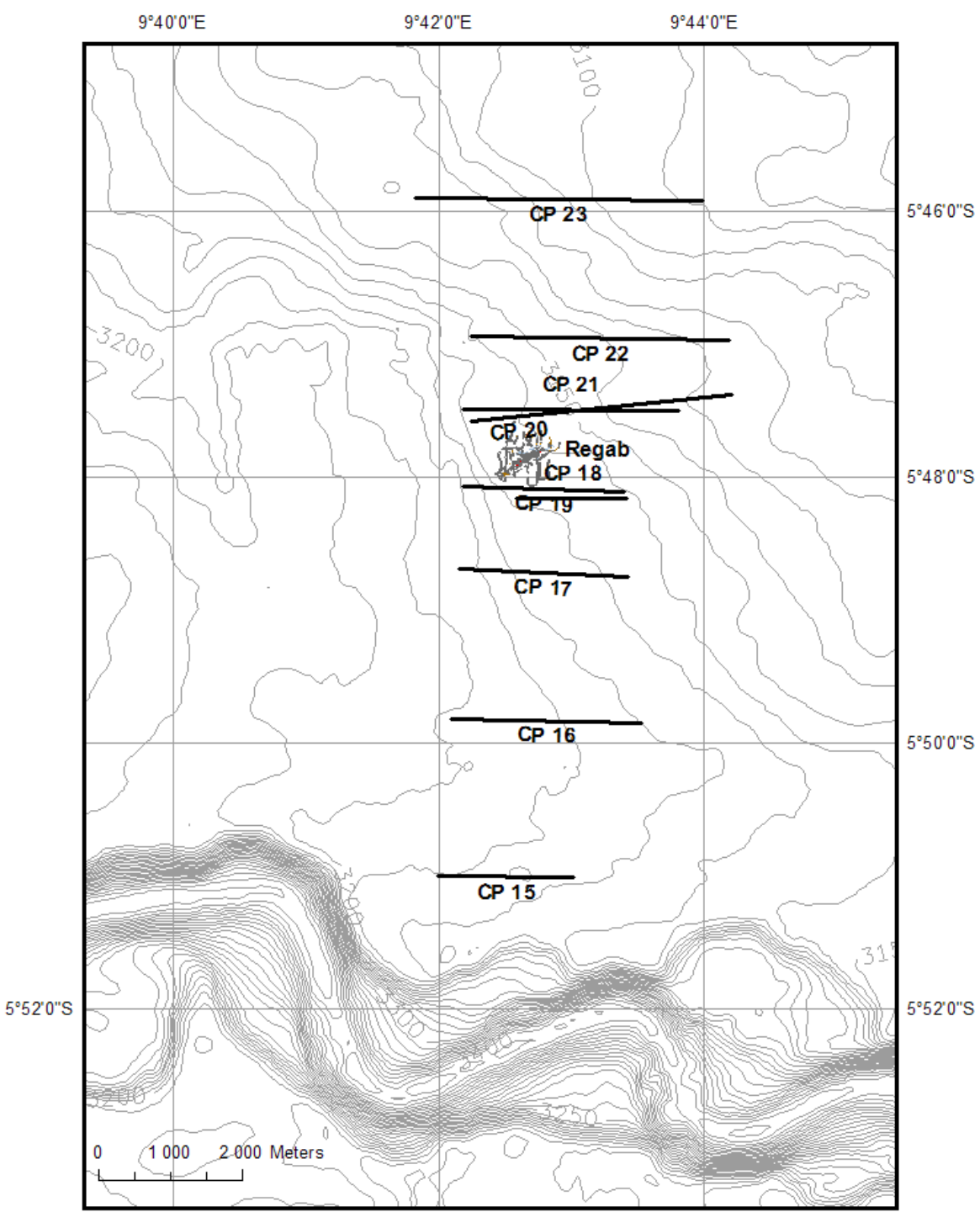

b. 


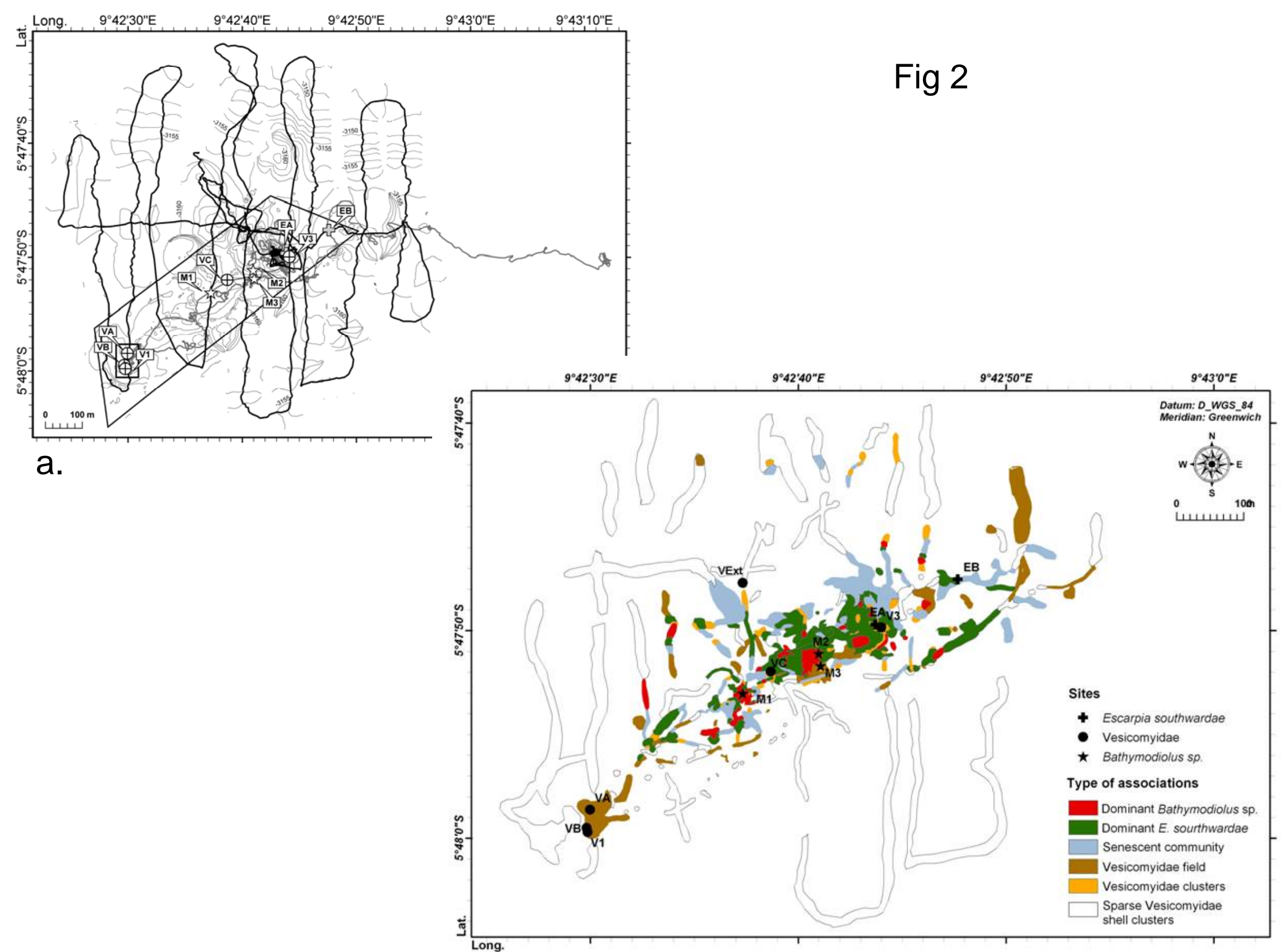

b. 

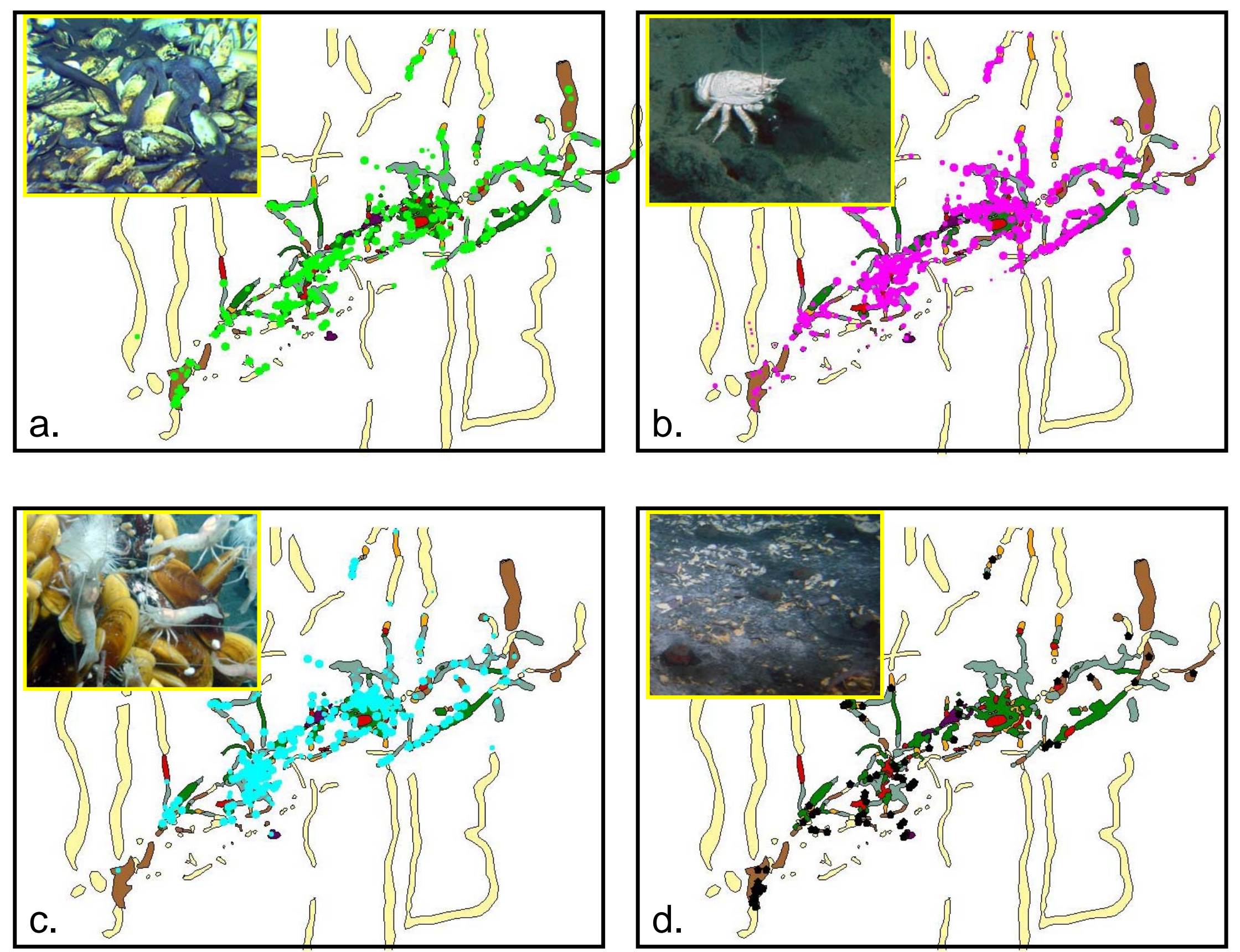

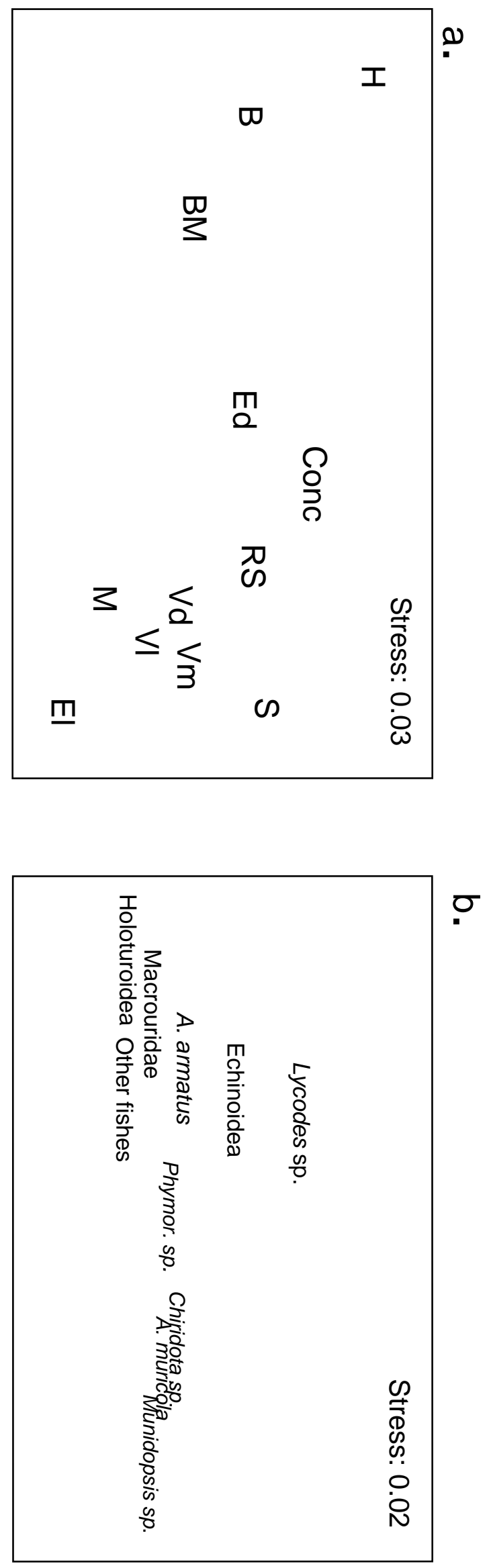


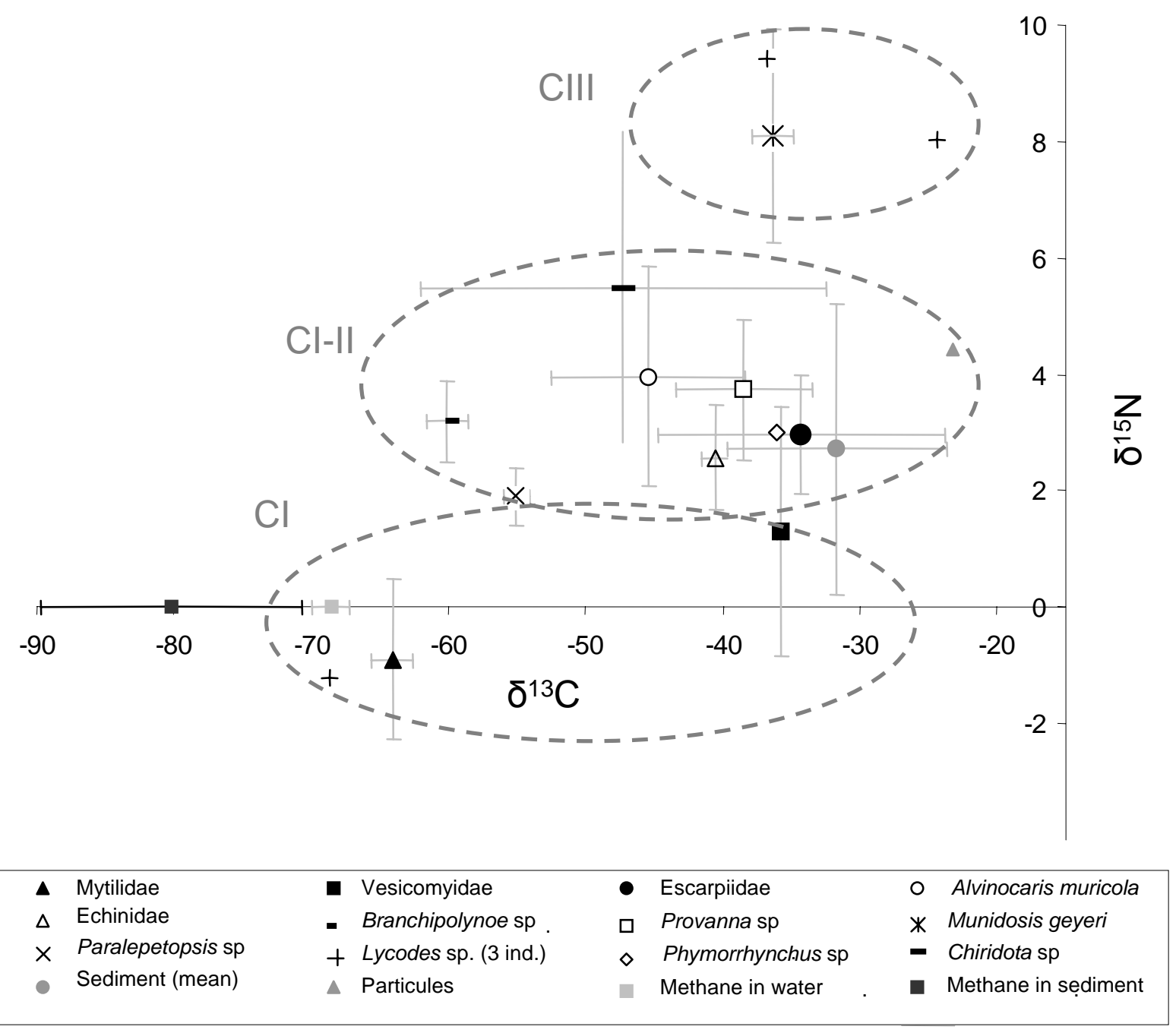


a.

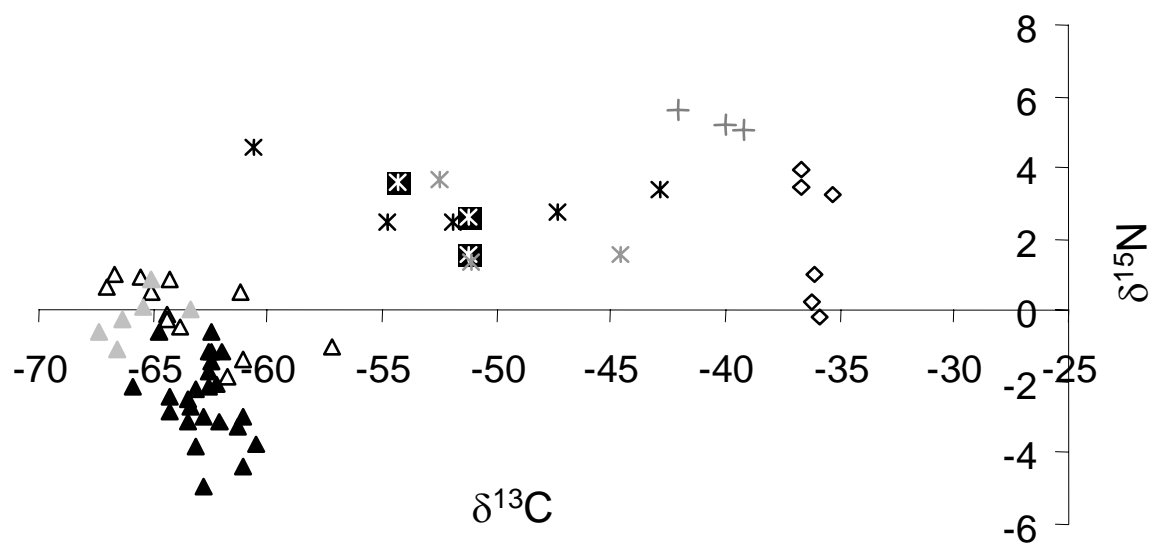

b.

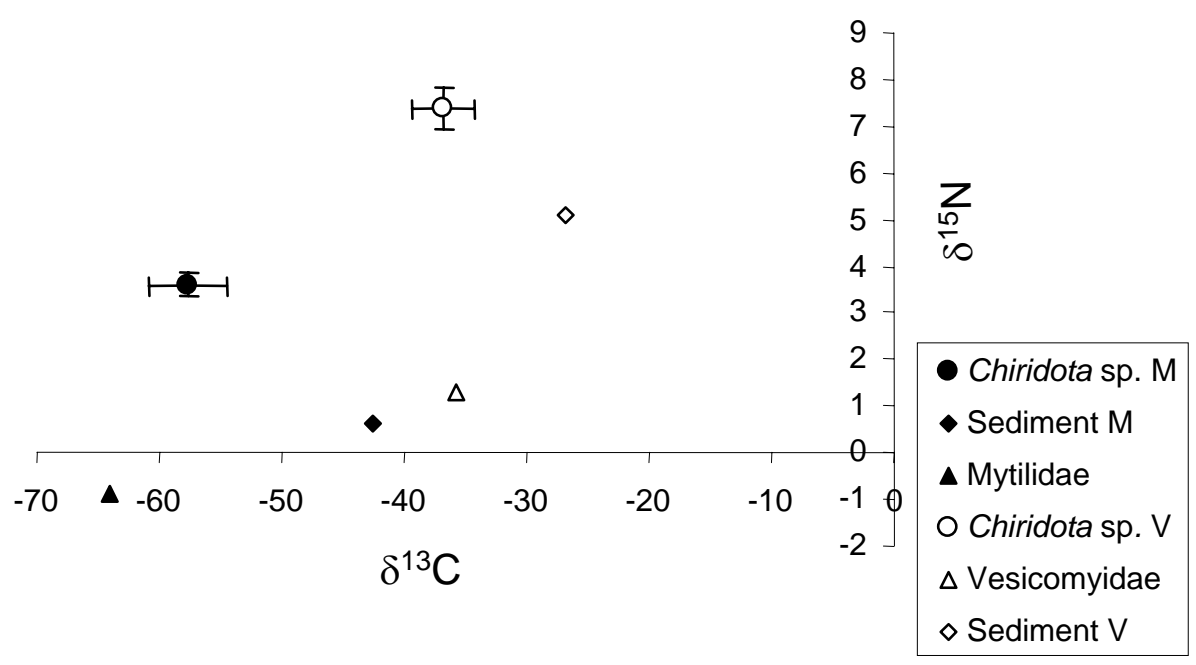

c.

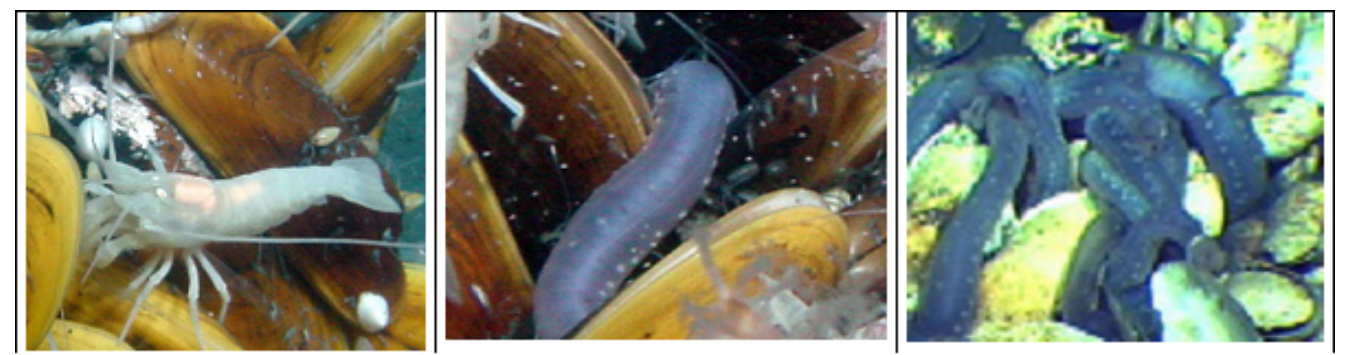


Table 1.

Characteristics of the sampling sites based on dominant symbiont-bearing species.

\begin{tabular}{|c|c|c|c|c|}
\hline Site & Dominant species & Percentage of living individuals & Cluster size $\left(\mathrm{m}^{2}\right)$ & Other comments \\
\hline M1 & Mytilidae Bathymodiolus aff. boomerang ${ }^{\mathrm{a}}$ & 100 & 400 & \\
\hline M2 & B. aff. boomerang & 100 & 1 & \\
\hline M3 & B. aff. boomerang ${ }^{\text {a }}$ & 100 & 4 & \\
\hline V1 & Vesicomyidae: Laubiericoncha chuni & $>80$ & 4 & External, main large field \\
\hline VB & Vesicomyidae & 0 & Unknown & External, main large field \\
\hline Vext & Vesicomyidae & C. 50 & 0.45 & External, isolated cluster \\
\hline V3 & Vesicomyidae: Calyptogena regab & $>80$ & 0.35 & Central zone \\
\hline VC & Vesicomyidae & $>80$ & 0.75 & Central zone \\
\hline EA & Siboglinidae: Escarpia southwardae & c. 100 & $<0.5$ & Adults (>1.5 m long) \\
\hline EB & E. southwardae & c. 100 & $<0.25$ & Young bush (<0.5 m long) \\
\hline
\end{tabular}


Table 2.

Densities (ind $\mathrm{m}^{-2}$ ) (a) and biomass ( $\mathrm{g}$ dry weight $\mathrm{m}^{-2}$ ) (b) of megafauna species from image analysis and sampling in the clusters defined by symbiont-bearing species (M: clusters dominated by mytilids; $\mathrm{V}$ : by vesicomyids, $\mathrm{E}$ : by escarpiids).

\begin{tabular}{|c|c|c|c|c|c|c|c|c|c|c|}
\hline & M1 & M2 & M3 & V3 & VC & V1 & VB & Vext & EA & EB \\
\hline \multicolumn{11}{|l|}{ (a) } \\
\hline \multicolumn{11}{|c|}{ Symbiont-bearing species } \\
\hline \multicolumn{11}{|l|}{ Bivalvia } \\
\hline B. aff. boomerang & 591.7 & 1066.7 & 869.4 & & & & & & & \\
\hline Vesicomyidae & & & & 741.6 & 607.5 & 586.4 & 0 (sh.) & 66.7 & & \\
\hline \multicolumn{11}{|l|}{ Polychaeta } \\
\hline E. southwardae & 125.0 & & 189.2 & & & & & & 769.1 & 250.0 \\
\hline \multicolumn{11}{|l|}{ Associated species } \\
\hline Actiniaria & 52.8 & 13.5 & 3.03 & & & & & 4.2 & & \\
\hline \multicolumn{11}{|l|}{ Gastropoda } \\
\hline Paralepetopsis sp. & 227.8 & 236.3 & 68.7 & & & & & & 79.5 & \\
\hline Provanna sp. & 508.3 & 87.8 & 129.3 & 210.4 & 38.8 & 67.8 & & & 105.8 & \\
\hline
\end{tabular}




\begin{tabular}{|c|c|c|c|c|c|c|c|c|c|c|}
\hline & M1 & M2 & M3 & V3 & VC & V1 & VB & Vext & EA & EB \\
\hline Phymorhynchus sp. & & & & & 3.0 & 30.3 & 27.8 & & 2.8 & \\
\hline \multicolumn{11}{|l|}{ Crustacea } \\
\hline Alvinocaris muricola & 450.0 & 344.3 & 743.7 & 245.6 & 53.4 & 0.7 & 55.6 & 0 & 302.4 & 58.5 \\
\hline Munidopsis geyeri & & & & & & 8.1 & 27.8 & & & 2.7 \\
\hline \multicolumn{11}{|l|}{ Holothuridea } \\
\hline Chiridota sp. & 2.8 & 6.8 & & 93.3 & 4.9 & & 111.1 & & & 31.9 \\
\hline \multicolumn{11}{|l|}{ Chordata } \\
\hline Lycodes sp. & & & & & & 2.8 & & 2.1 & & \\
\hline Total & 1958.3 & 1741.8 & 2003.2 & 1290.9 & 707.5 & 696.1 & 222.3 & 73.0 & 1256.7 & 343.1 \\
\hline Associated species & 1313.9 & 675.1 & 1130.9 & 549.3 & 100.0 & 107.0 & 222.3 & 6.3 & 487.6 & 93.08 \\
\hline (b) & & & & & & & & & & \\
\hline
\end{tabular}




\begin{tabular}{|c|c|c|c|c|c|c|c|c|c|c|}
\hline & M1 & M2 & M3 & V3 & VC & V1 & VB & Vext & EA & EB \\
\hline \multicolumn{11}{|c|}{ Symbiont-bearing species } \\
\hline \multicolumn{11}{|l|}{ Bivalvia } \\
\hline B. aff. boomerang & 1966.9 & 3546.0 & 2890.2 & & & & & & & \\
\hline Vesicomyidae & & & & 1964.5 & 1609.2 & 1553.2 & 0 & 0 & & \\
\hline \multicolumn{11}{|l|}{ Polychaeta } \\
\hline E. southwardae & 91.4 & & 138.4 & & & & & & 562.2 & 90.0 \\
\hline \multicolumn{11}{|l|}{ Associated species } \\
\hline Actiniaria & n. e. & & & & & & & n.e. & & \\
\hline \multicolumn{11}{|l|}{ Gastropoda } \\
\hline Paralepetopsis sp. & 1.8 & 1.8 & 0.53 & & & & & & 0.64 & \\
\hline Provanna sp. & 10.4 & 1.8 & 2.65 & 4.3 & 0.8 & 1.4 & & & 2.22 & \\
\hline Phymorhynchus sp. & & & & & 3.0 & 29.9 & 27.5 & & 2.8 & \\
\hline \multicolumn{11}{|l|}{ Crustacea } \\
\hline Alvinocaris muricola & 255.0 & 195.1 & 421.4 & 139.2 & 30.2 & 0.4 & 31.5 & 0 & 171.3 & 33.2 \\
\hline
\end{tabular}




\begin{tabular}{|c|c|c|c|c|c|c|c|c|c|c|}
\hline & M1 & M2 & M3 & V3 & VC & V1 & VB & Vext & EA & EB \\
\hline Munidopsis geyeri & & & & & & 23.0 & 78.6 & & & 7.5 \\
\hline \multicolumn{11}{|l|}{ Holothuridea } \\
\hline Chiridota sp. & 3.4 & 8.3 & & 114.6 & 6.0 & & 136.4 & & & 0.7 \\
\hline \multicolumn{11}{|l|}{ Chordata } \\
\hline Lycodes sp. & & & & & & n.e. & & n.e. & & \\
\hline Total & $>2329$ & 3753.1 & 3453.2 & 2222.6 & 1649.1 & $>1608$ & 222.3 & n.e. & 736.4 & 126.4 \\
\hline Associated species & 270.6 & 207.1 & 401.3 & 258 & 39.9 & 54.8 & 222.3 & n.e. & 174.2 & 36.4 \\
\hline
\end{tabular}

n.e.: non-estimated. 
Table 3.

Isotopic carbon signature $\left(\delta^{13} \mathrm{C}\right)$ of methane extracted from sediment or expelled fluid on the REGAB pockmark.

\begin{tabular}{|l|l|l|l|}
\hline Sampling site & Sample type & $\mathbf{\%} \mathbf{C H}_{\mathbf{4}}$ & $\mathbf{\delta}^{\mathbf{1 3}} \mathbf{C} \mathbf{C H}_{\mathbf{4}} \mathbf{( \% )}$ \\
\hline Vesicomyid field & Sediment & 100 & -82 \\
\hline Regab centre & Sediment & 99.8 & -81 \\
\hline Regab centre & Gas from sediment core & 99.8 & -84.3 \\
\hline Hydrate outcrop & Gas from sediment core & 100 & -68.5 \\
\hline Next to M2 & Sediment & 99.94 & -68.7 \\
\hline Next to M1 & Sediment & $99.87 / 99.92$ & $-84.8 /-96.2$ \\
\hline Regab centre & Fluid & 99.941 & -70.4 \\
\hline Regab centre & Fluid & 99.954 & -68.69 \\
\hline Regab bubble site & Fluid & 99.989 & -67.3 \\
\hline Regab bubble site & Fluid & 99.955 & -67.9 \\
\hline
\end{tabular}

Table 4.

Isotopic signatures of sediment and particles sampled by cores or traps in and off the REGAB pockmark.

\begin{tabular}{|l|l|l|l|l|}
\hline Sample & $\boldsymbol{\delta}^{13} \mathrm{C}(\%)$ mean & $\boldsymbol{\delta}^{13} \mathrm{C}(\%)$ sd & $\boldsymbol{\delta}^{15} \mathrm{~N}(\%)$ mean & $\boldsymbol{\delta}^{15} \mathrm{~N}(\%)$ sd \\
\hline Sediment M1 & -30.9 & & 0.14 & \\
\hline
\end{tabular}




\begin{tabular}{|l|l|l|l|l|}
\hline Sample & $\boldsymbol{\delta}^{\mathbf{1 3}} \mathbf{C}(\%)$ mean & $\boldsymbol{\delta}^{\mathbf{1 3}} \mathbf{C}(\%) \mathbf{~ s d}$ & $\boldsymbol{\delta}^{\mathbf{1 5}} \mathbf{N}(\%)$ mean & $\boldsymbol{\delta}^{\mathbf{1 5}} \mathbf{N}(\%) \mathbf{~ s d}$ \\
\hline Sediment M2 & -47.69 & 2.37 & 1.36 & 0.34 \\
\hline Sediment M3 & -29.46 & & 0.07 & \\
\hline Sediment V1 & -25.58 & & 5.72 & \\
\hline Sediment V2 & -26.4 & & 3.92 & \\
\hline Sediment V3 & -28.04 & 0.72 & 4.44 & 0.37 \\
\hline Particulars from traps & -23.22 & & 4.43 & \\
\hline Sediment 600 m/1700 m from Regab & -23.77 & 0.59 & 7.88 & 0.03 \\
\hline
\end{tabular}

Table 5.

Isotopic signatures of symbiont-bearing species from different sampling sites in the REGAB pockmark.

\begin{tabular}{|l|l|l|l|l|l|l|}
\hline Species/sites & $\boldsymbol{\delta}^{13} \mathbf{C}(\%)$ mantle & $\boldsymbol{\delta}^{13} \mathbf{c}(\%)$ gill & $\boldsymbol{\delta}^{15} \mathbf{N}(\%)$ mantle & $\boldsymbol{\delta}^{15} \mathbf{N}(\%)$ gill & $\boldsymbol{\delta}^{13} \mathbf{C}(\%)$ mean $^{*}$ & $\boldsymbol{\delta}^{15} \mathbf{N}(\%)$ mean $^{*}$ \\
\hline Bathymodiolus aff. boomerang \\
\hline M1 & $-63.3 \pm 3.5(12)$ & $-63.7 \pm 2.1$ & $-0.5 \pm 0.8(12)$ & $-0.6 \pm 0.3$ & & \\
\hline M3 & $-64.5 \pm 0.8(6)$ & $-67.0 \pm 0.8$ & $0.3 \pm 0.5(6)$ & $-0.7 \pm 0.4$ & & \\
\hline & $-63.7 \pm 1.5(24)$ & $-62.4 \pm 0.9$ & $-1.9 \pm 0.9(24)$ & $-3.1 \pm 1.0$ & & \\
\hline
\end{tabular}




\begin{tabular}{|c|c|c|c|c|c|c|}
\hline Species/sites & $\delta^{13} \mathrm{C}(\%)$ mantle & $\delta^{13} c(\%)$ gill & $\delta^{15} \mathrm{~N}(\% 0)$ mantle & $\delta^{15} \mathrm{~N}(\%)$ gill & $\delta^{13} C(\%)$ mean* & $\delta^{15} \mathrm{~N}(\%)$ mean $^{*}$ \\
\hline V1 & $-35.6 \pm 1.6(5)$ & $-35.7 \pm 1.1$ & $2.9 \pm 2.0(5)$ & $-1.0 \pm 2.1$ & & \\
\hline V3 & $-36.0 \pm 0.8(5)$ & $-36.0 \pm 0.15$ & $3.5 \pm 0.3(5)$ & $2.9 \pm 2.0$ & & \\
\hline \multicolumn{7}{|c|}{ Escarpia southwardae } \\
\hline M1 & & & & & $-24.2 \pm 5.5(5)$ & $2.5 \pm 1.6(5)$ \\
\hline EA (adults) & & & & & $-36.22 \pm 3.3(5)$ & $2.9 \pm 0.6(5)$ \\
\hline EB (youngs) & & & & & $-29.1 \pm 3.4(3)$ & - \\
\hline
\end{tabular}

Table 6.

Mean isotopic signatures of associated megafauna sampled by ROV in the clusters dominated either by mytilids (M), vesicomyids (V) or escarppids (E) or by trawl (CP20) in the REGAB cold-seep site.

\begin{tabular}{|l|l|l|l|l|l|}
\hline Species & Site & $\delta^{13} \mathbf{C}(\%)$ mean & $\delta^{13} \mathbf{C}(\%)$ sd (n) & $\delta^{15} \mathbf{N}(\%)$ mean & $\delta^{15} \mathbf{N}(\%)$ sd (n) \\
\hline \begin{tabular}{l} 
Polychaeta \\
\hline Branchipolynoe sp.
\end{tabular} & M1 & -60.09 & - & 2.46 & - \\
\hline \multicolumn{7}{|l|}{} \\
\hline Gastropoda & VB,E2E3 & -35.12 & $1.66(6)$ & 3.89 & $1.33(6)$ \\
\hline Provanna sp. & CP20 & -44.31 & $4.43(5)$ & 4.71 & $0.49(5)$ \\
\hline
\end{tabular}




\begin{tabular}{|c|c|c|c|c|c|}
\hline Species & Site & $\delta^{13} \mathrm{C}(\%)$ mean & $\delta^{13} \mathrm{C}(\% 0) \mathrm{sd}(n)$ & $\delta^{15} \mathrm{~N}(\%)$ mean & $\delta^{15} \mathrm{~N}(\%)$ sd (n) \\
\hline Paralepetopsis sp. & M1 & -55.0 & - & 1.9 & - \\
\hline \multirow[t]{2}{*}{ Phymorrhynchus sp. } & E2 & -36.13 & $1.46(3)$ & No value & - \\
\hline & CP20 & -36.03 & $1.51(5)$ & 2.99 & $0.41(5)$ \\
\hline \multicolumn{6}{|l|}{ Crustacea } \\
\hline \multirow[t]{3}{*}{ Alvinocaris muricola } & M1M2M3 & -50.4 & $0.92(11)$ & 2.6 & $0.45(11)$ \\
\hline & V3 & -40.4 & $1.47(3)$ & 5.3 & $0.26(3)$ \\
\hline & CP20 & -38.5 & $2.03(3)$ & 4.40 & $0.54(3)$ \\
\hline \multirow[t]{2}{*}{ Munidosis geyeri } & E2 & -36.31 & - & 9.37 & - \\
\hline & CP20 & -36.33 & $1.05(3)$ & 6.50 & $0.42(3)$ \\
\hline Munidopsis hirtella & CP20 & -22.4 & - & 11.25 & - \\
\hline \multicolumn{6}{|l|}{ Echinodermata } \\
\hline \multirow[t]{2}{*}{ Chiridota sp. } & M1M3 & -57.06 & $5.59(5)$ & 3.93 & $1.96(5)$ \\
\hline & CP20 & -36.78 & $1.84(2)$ & 7.37 & $0.49(2)$ \\
\hline Echinidae sp. & Near to M3 & -41.29 & $2.53(3)$ & 1.95 & $1.25(3)$ \\
\hline
\end{tabular}




\begin{tabular}{|l|l|l|l|l|l|}
\hline Species & Site & $\boldsymbol{\delta}^{13} \mathbf{C}(\%)$ mean & $\boldsymbol{\delta}^{13} \mathbf{C}(\%)$ sd (n) & $\boldsymbol{\delta}^{15} \mathrm{~N}(\%)$ mean & $\boldsymbol{\delta}^{\mathbf{1 5}} \mathrm{N}(\%)$ sd (n) \\
\hline Chordata & & & & & \\
\hline Lycodes sp. & CP20 & -43.23 & $22.83(3)$ & 5.41 & $5.79(3)$ \\
\hline
\end{tabular}

Table 7.

Isotopic signature $\left(\delta^{13} \mathrm{C}\right)$ of fishes sampled by trawls at increasing distance from the REGAB site and estimated percentages of chemosynthetic material in their diet.

\begin{tabular}{|c|c|c|c|c|c|c|c|c|c|}
\hline \multirow[b]{2}{*}{ Trawls } & \multicolumn{7}{|c|}{$\delta^{13} \mathrm{C}(\%)$ mean $(n)$} & \multirow{2}{*}{ Mean } & \multirow{2}{*}{$\begin{array}{l}\text { \% chemosynthetic } \\
\text { material }\end{array}$} \\
\hline & CP17 & CP18 & CP19 & CP20 & CP21 & CP22 & CP23 & & \\
\hline Distance from REGAB & $1560 \mathrm{~m}$ & $580 \mathrm{~m}$ & $400 \mathrm{~m}$ & $610 \mathrm{~m}$ & $680 \mathrm{~m}$ & $1660 \mathrm{~m}$ & $3600 \mathrm{~m}$ & & \\
\hline Acantaurus armatus & $\begin{array}{l}-20.1 \\
(2)\end{array}$ & & $\begin{array}{l}-21.8 \\
(3)\end{array}$ & -22.7 & -19.3 & $\begin{array}{l}-22.4 \\
(2)\end{array}$ & -22.0 & $-21.4 \pm 1.6$ & $4-27$ \\
\hline Bassossetus robustus & $\begin{array}{l}-20.6 \\
(2)\end{array}$ & & & & -25.0 & $\begin{array}{l}-21.2 \\
(4)\end{array}$ & $\begin{array}{l}-23.2 \\
(2)\end{array}$ & $-21.7 \pm 1.6$ & $16-39$ \\
\hline $\begin{array}{l}\text { Coryphaenoides } \\
\text { striaturus }\end{array}$ & -18.8 & & & & & & -18.8 & $-18.8 \pm 0.6$ & 7 \\
\hline Porogadus milles & $\begin{array}{l}-21.5 \\
(2)\end{array}$ & -22.0 & & -18.6 & & -21.0 & & $-21.0 \pm 1.5$ & $6-23$ \\
\hline Malacoteus niger & & -18.7 & & & & & & $-18.7 \pm 1.0$ & 6 \\
\hline
\end{tabular}




\begin{tabular}{|c|c|c|c|c|c|c|c|c|c|}
\hline \multirow[b]{2}{*}{ Trawls } & \multicolumn{7}{|c|}{$\delta^{13} \mathrm{C}(\%)$ mean $(n)$} & \multirow{2}{*}{ Mean } & \multirow{2}{*}{$\begin{array}{l}\% \text { chemosynthetic } \\
\text { material }\end{array}$} \\
\hline & CP17 & CP18 & CP19 & CP20 & CP21 & CP22 & CP23 & & \\
\hline Distance from REGAB & $1560 \mathrm{~m}$ & $580 \mathrm{~m}$ & $400 \mathrm{~m}$ & $610 \mathrm{~m}$ & $680 \mathrm{~m}$ & $1660 \mathrm{~m}$ & $3600 \mathrm{~m}$ & & \\
\hline Scopeloberyx robustus & & -18.5 & & & -212 & & & $-19.9 \pm 1.6$ & 19 \\
\hline $\begin{array}{l}\text { Holcomysteronus } \\
\text { squamosus }\end{array}$ & & & -21.3 & -28.3 & & & & $-24.8 \pm 3.8$ & $20-56$ \\
\hline Stomias boa boa & & & $\begin{array}{l}-18.1 \\
(2)\end{array}$ & & & -15.9 & & $-17.5 \pm 1.7$ & $0-3$ \\
\hline Stylephorus chordatus & & & -20.7 & & -22.6 & & & $-21.8 \pm 1.1$ & $17-26$ \\
\hline $\begin{array}{l}\text { Histobranchius } \\
\text { bathybius }\end{array}$ & & & & & & -18.0 & & $-18.0 \pm 0.1$ & 0 \\
\hline Manducus maderensis & & & & -21.1 & & -16.9 & & $-19.0 \pm 2.6$ & 6 \\
\hline Lycodes sp. & & & & $\begin{array}{l}-45.2 \\
(3)\end{array}$ & & & & $-45.2 \pm 19.7$ & $35-100$ \\
\hline Munidopsis geyeri & & & $\begin{array}{l}-34.4 \\
(2)\end{array}$ & $\begin{array}{l}-36.3 \\
(3)\end{array}$ & & & & & 86-100 \\
\hline Munidopsis hirtella & & & $\begin{array}{l}-23.6 \\
(2)\end{array}$ & -22.0 & & -21.4 & & & $19-31$ \\
\hline
\end{tabular}

